\title{
Synthesis and Anti-Chikungunya Virus (CHIKV) Activity of Novel 1,4-Naphthoquinone Sulfonamide and Sulfonate Ester Derivatives
}

\author{
Paulo A. F. Pacheco, ${ }^{\circledR a}$ Daniel T. Gonzaga, ${ }^{\circledR b}$ Cláudio C. Cirne-Santos, ${ }^{\circledR c}$ Caroline S. Barros, ${ }^{\oplus c}$ \\ Max W. L. Gomes, ${ }^{c}$ Rafaela S. P. Gomes, ${ }^{c}$ Mariana C. Gonçalves, ${ }^{b}$ Vitor F. Ferreira, ${ }^{\circledR a}$ \\ Vitor W. Rabelo, ${ }^{\circ c}$ Paula A. Abreu, ${ }^{\odot d}$ Robson X. Faria, ${ }^{\oplus e}$ Gabriel O. de Resende, ${ }^{\circ} f$ \\ David R. da Rocha, ${ }^{\circledR a}$ Izabel C. N. P. Paixão ${ }^{\circledR *, c}$ and Fernando C. da Silva ${ }^{\circledR *, a}$
}

${ }^{a}$ Departamento de Química Orgânica, Instituto de Química, Universidade Federal Fluminense, Campus do Valonguinho, 24020-141 Niterói-RJ, Brazil

${ }^{b}$ Unidade de Farmácia (UFAR), Fundação Centro Universitário da Zona Oeste, 23070-200 Rio de Janeiro-RJ, Brazil

'Programa de Pós-Graduação em Ciências e Biotecnologia, Laboratório de Virologia Molecular e Biotecnologia Marinha, Departamento de Biologia Celular e Molecular, Instituto de Biologia, Universidade Federal Fluminense, 24020-141 Niterói-RJ, Brazil

${ }^{d}$ Instituto de Biodiversidade e Sustentabilidade, Universidade Federal do Rio de Janeiro, 27965-045 Macaé-RJ, Brazil

${ }^{e}$ Laboratório de Avaliação e Promoção da Saúde Ambiental, Fundação Oswaldo Cruz, Pavilhão Lauro Travassos, Instituto Oswaldo Cruz, Manguinhos, 21045-900 Rio de Janeiro-RJ, Brazil

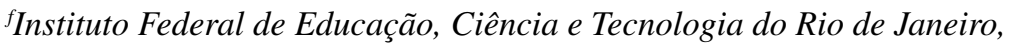
Unidade Maracanã, 20270-021 Rio de Janeiro-RJ, Brazil

\begin{abstract}
Chikungunya virus (CHIKV) is a re-emerging disease caused by an alphavirus of the Togaviridae family. Since its first description in 1952, the disease has spread worldwide, affecting populations in both tropical and temperate countries. To date, there is no licensed vaccine or specific pharmacological treatment. Therefore, there is an increasing urgency in developing new antiviral drugs capable of specifically inhibiting viral replication. In the present work, we report the synthesis and antiviral activity evaluation of nineteen naphthoquinone derivatives, containing a sulfonamide or sulfonate group. Cell viability assays indicated a low toxic potential for all tested compounds and inhibitory assays against CHIKV identified five compounds with potent activity. The compounds were also evaluated for their virucidal potential, and the results demonstrated that compound 11a exhibited a virucidal effect higher than $70 \%$ in the treatment with $20 \mu \mathrm{M}$. Furthermore, in silico studies were performed to predict the antiviral drug targets.
\end{abstract}

Keywords: Chikungunya virus, naphthoquinone, sulfonamide, sulfonate

\section{Introduction}

Quinones constitute a class of natural products with wide distribution in nature and are structurally characterized by two conjugated carbonyl groups in sixmembered unsaturated rings. ${ }^{1}$ Naphthoquinone presents

*e-mail: izabeluff@gmail.com; fcsilva@id.uff.br

Editor handled this article: Brenno A. D. Neto (Associate) an aromatic ring fused to the quinonoid nucleus, and this chemical characteristic is identified as responsible for its redox potential. ${ }^{2}$ Naphthoquinones are considered privileged structures in Medicinal Chemistry and have been extensively studied as synthetic platforms due to their broad range of biological properties, such as anticancer, antibacterial, anti-inflammatory, antiviral, and others. ${ }^{3-9}$

Chikungunya virus (CHIKV) is a mosquito-transmitted alphavirus of the Togaviridae family that causes a febrile 
syndrome (Chikungunya fever) usually associated with intense and debilitating arthralgia. ${ }^{10-12}$ It was first described in 1952 during an outbreak in southern Tanzania. ${ }^{13}$ Since then, it has spread, and infection cases have been reported in all continents, except Antarctica and approximately 3-5 million cases of CHIKV are reported each year worldwide. ${ }^{14}$ The disease is transmitted during blood repast of peridomestic mosquitoes, such as Aedes aegypti and Aedes albopictus..$^{15,16}$

Although research has brought compounds with activity against CHIKV, most of them have not yet been validated in vivo and in clinical trials. Thus, until now, neither specific antivirals drugs nor a licensed vaccine are available. Chikungunya fever therapy is based on supportive measures and the treatment of symptoms through non-steroidal anti-inflammatory drugs (NSAIDs) and fluid therapy. ${ }^{17}$ This shows that the effort to find a specific treatment is extremely important. The sulfonamide group $\left(-\mathrm{SO}_{2} \mathrm{NH}_{2}\right)$ is found in the structure of several drugs with high clinical relevance, such as sulfamethoxazole (1, antibacterial), acetazolamide (2, carbonic anhydrase inhibitors), celecoxib (3, cyclooxygenase-2 inhibitor), and glibenclamide (4, hypoglycemic agent) (Figure 1), ${ }^{7,18-20}$ Other biological activities have also been reported by compounds containing this functionality, such as anticancer, antimicrobial, anti-inflammatory, antioxidant, and others. ${ }^{21-24}$ Regarding antiviral activity, sulfonamide moiety is present in the compound structure used clinically to treat viral infections, such as amprenavir (5) and darunavir $(\mathbf{6}) .^{25,26}$

Herein, we describe the synthesis of two series of naphthoquinones derivatives containing a sulfonamide group (8a-8e, 9a-9e, and 10a-10d) and sulfonate esters group (11a-11e). Additionally, all synthesized compounds were also screened in vitro for their cytotoxicity and antiCHIKV activity.

\section{Experimental}

\section{Chemistry}

\section{Materials and methods}

The solvents and reagents were obtained from Merck (São Paulo, Brazil) and used without further purification. For qualitative monitoring of the reaction progress, analytical thin-layer chromatography (TLC) was produced with silica gel plates (Merck, São Paulo, Brazil, TLC silica gel 60 F254), and the plots were visualized using UV light (Sigma-Aldrich, São Paulo, Brazil). For purification of the final compounds, column chromatography was performed with silica gel 60 (Merck 70-230 mesh, São Paulo, Brazil). Melting points, when necessary, were obtained on a Thermo Scientific 9100 apparatus (Waltham, USA) and were uncorrected. All final products were submitted to complete spectroscopic characterization. Infrared spectra were measured with $\mathrm{KBr}$ pellets on a PerkinElmer model 1420 Fourier transform infrared (FTIR) spectrophotometer (São Paulo, Brazil), and the spectra were calibrated using the $1601.8 \mathrm{~cm}^{-1}$ polystyrene absorbances. Nuclear magnetic resonance (NMR) spectra were obtained with a Varian Unity Plus VXR $500 \mathrm{MHz}$ (Palo Alto, USA) instrument in dimethyl sulfoxide (DMSO- $d_{6}$ ) solutions. The chemical shift data were reported in units of $\delta(\mathrm{ppm})$ downfield from tetramethylsilane (TMS) or the solvent, either of which was used as an internal standard, coupling constants $(J)$ are reported in hertz and refer to apparent peak multiplicities. High-resolution mass spectra<smiles>Cc1cc(NS(=O)(=O)c2ccc(N)cc2)no1</smiles>

(1)<smiles>CC(=O)Nc1nnc(S(N)(=O)=O)s1</smiles>

(2)<smiles>Cc1ccc(-c2cc(C(F)(F)F)nn2-c2ccc(S(N)(=O)=O)cc2)cc1</smiles>

(3)<smiles>CC(C)CN(CC(O)C(Cc1ccccc1)NC(=O)OC1COC2OCCC12)S(=O)(=O)c1ccc(N)cc1</smiles>

(5)

(4)<smiles>CCCCC(Cc1ccccc1)NC(=O)OC1CCOC1</smiles>

(6)

Figure 1. Commercial drugs containing a sulfonamide moiety. 
(HRMS) were recorded on a MICROMASS Q-TOF mass spectrometer (Waters, Milford, USA).

\section{General procedure for $\mathbf{8 a - 8 e , 9 a - 9 e , ~ a n d ~} \mathbf{1 0 a - 1 0 d}$ preparation}

The corresponding amino-naphthoquinone (7a7c) $(1 \mathrm{mmol})$ was dissolved with pyridine $(4 \mathrm{~mL})$ under magnetic stirring in a round-bottom flask. Next, 4-dimethylaminopyridine (DMAP) $(0.1 \mathrm{mmol})$ and the appropriate sulfonyl chloride $(1.5 \mathrm{mmol})$ were added to the reaction flask, and the mixture was stirred for $24 \mathrm{~h}$ at room temperature. After the start material total consumption, the aqueous solution of $\mathrm{HCl} 1 \mathrm{M}$ was added to neutralize the medium, and the resulting mixture was extracted with ethyl acetate. The organic phase was washed successively with saturated $\mathrm{NaHCO}_{3}$ solution, water, and brine, dried over sodium sulfate anhydrous, and evaporated under reduced pressure. The resulting crude product was purified in silicagel column chromatography using a gradient mixture of hexane/ethyl acetate as eluent to obtain the pure derivatives.

$N$-(4-((1,4-Dioxo-1,4-dihydronaphthalen-2-yl)amino)phenyl) benzenesulfonamide (8a)

Dark brown solid; yield $>99 \%$ ( $400 \mathrm{mg}$ ); $\mathrm{mp} 241-243^{\circ} \mathrm{C}$; IR $(\mathrm{KBr}) \vee / \mathrm{cm}^{-1} 723,831,920,1226,1340,1449,1607$, 1669,$3304 ;{ }^{1} \mathrm{H}$ NMR $\left(500 \mathrm{MHz}, \mathrm{DMSO}-d_{6}\right) \delta 5.96(\mathrm{~s}, 1 \mathrm{H})$, $7.15(\mathrm{~d}, 2 \mathrm{H}, J 8.8 \mathrm{~Hz}), 7.25(\mathrm{~d}, 2 \mathrm{H}, J 8.8 \mathrm{~Hz}), 7.53-7.56(\mathrm{~m}$, $2 \mathrm{H}), 7.62-7.59(\mathrm{~m}, 1 \mathrm{H}), 7.74-7.78(\mathrm{~m}, 3 \mathrm{H}), 7.83(\mathrm{td}, 1 \mathrm{H}$, $J 1.3$ and $7.5 \mathrm{~Hz}), 7.94(\mathrm{dd}, 1 \mathrm{H}, J 0.9$ and $7.7 \mathrm{~Hz}), 8.03(\mathrm{dd}$, $1 \mathrm{H}, J 0.9$ and $7.7 \mathrm{~Hz}), 8.91(\mathrm{~s}, 1 \mathrm{H}), 10.16(\mathrm{~s}, 1 \mathrm{H}) ;{ }^{13} \mathrm{C} \mathrm{NMR}$ (125 MHz attached proton test (APT), DMSO- $d_{6}$ ) $\delta 101.8$, 121.1, 124.2, 125.0, 125.7, 126.4, 128.9, 130.2, 132.2, 132.4, 132.5, 134.1, 134.5, 134.6, 139.5, 145.9, 181.2, 182.1; HRESIMS $m / z$, calcd. for $\mathrm{C}_{22} \mathrm{H}_{15} \mathrm{~N}_{2} \mathrm{O}_{4} \mathrm{~S}^{-}[\mathrm{M}-\mathrm{H}]^{-}$: 403.0758, found: 403.0772 .

$N$-(4-((1,4-Dioxo-1,4-dihydronaphthalen-2-yl)amino) phenyl)-4-methylbenzenesulfonamide (8b)

Dark brown solid; yield >99\% (414 mg); $\mathrm{mp} 227-229^{\circ} \mathrm{C}$; IR $(\mathrm{KBr}) \vee / \mathrm{cm}^{-1} 724,824,920,1157,1226,1340,1530$, 1607, 1670, 3121; ${ }^{1} \mathrm{H}$ NMR (500 MHz, DMSO- $d_{6}$ ) $\delta 2.35$ (s, 3H), $5.95(\mathrm{~s}, 1 \mathrm{H}), 7.15(\mathrm{~d}, 2 \mathrm{H}, J 8.9 \mathrm{~Hz}), 7.24(\mathrm{~d}, 2 \mathrm{H}$, $J 8.9 \mathrm{~Hz}), 7.34(\mathrm{~d}, 2 \mathrm{H}, J 8.4 \mathrm{~Hz}), 7.66(\mathrm{~d}, 2 \mathrm{H}, J 8.3 \mathrm{~Hz}), 7.75$ (td, $1 \mathrm{H}, J 1.3$ and $7.5 \mathrm{~Hz}$ ), 7.83 (td, $1 \mathrm{H}, J 1.3$ and $7.5 \mathrm{~Hz}$ ), $7.94(\mathrm{dd}, 1 \mathrm{H}, J 1.0$ and $7.6 \mathrm{~Hz}), 8.03(\mathrm{dd}, 1 \mathrm{H}, J 1.0$ and $7.6 \mathrm{~Hz}), 8.91$ (s, 1H), 10.09 (s, 1H); ${ }^{13} \mathrm{C}$ NMR $(125 \mathrm{MHz}$ APT, DMSO- $\left.d_{6}\right) \delta 20.6,101.8,121.0,124.2,125.0,125.7$, $126.4,129.3,130.2,132.2,132.5,133.9,134.5,134.7$, 136.7, 142.9, 145.9, 181.2, 182.1; HRESIMS $\mathrm{m} / \mathrm{z}$, calcd. for $\mathrm{C}_{23} \mathrm{H}_{18} \mathrm{~N}_{2} \mathrm{NaO}_{4} \mathrm{~S}^{+}[\mathrm{M}+\mathrm{H}]^{+}:$441.0879, found: 441.0879 .
$N$-(4-((1,4-Dioxo-1,4-dihydronaphthalen-2-yl)amino)phenyl) naphthalene-2-sulfonamide (8c)

Dark brown solid; yield $>99 \%$ ( $450 \mathrm{mg}$ ); $\mathrm{mp} 222-224^{\circ} \mathrm{C}$; IR $(\mathrm{KBr}) \vee / \mathrm{cm}^{-1} 725,822,924,1154,1229,1335,1454$, $1610,1665,3108$; ${ }^{1} \mathrm{H}$ NMR (500 MHz, DMSO- $\left.d_{6}\right) \delta 5.94$ $(\mathrm{s}, 1 \mathrm{H}), 7.18-7.23(\mathrm{~m}, 4 \mathrm{H}), 7.70-7.74(\mathrm{~m}, 2 \mathrm{H}), 7.75(\mathrm{td}, 1 \mathrm{H}$, $J 1.3$ and $7.6 \mathrm{~Hz}), 7.81-7.84(\mathrm{~m}, 2 \mathrm{H}), 7.93(\mathrm{dd}, 1 \mathrm{H}, J 0.9$ and 7.7 Hz), 7.99-8.03 (m, 2H), 8.07-8.11 (m, $2 \mathrm{H}), 8.42(\mathrm{~d}, 1 \mathrm{H}$, $J 1.4 \mathrm{~Hz}), 8.88$ (s, 1H), 10.29 (s, 1H); ${ }^{13} \mathrm{C}$ NMR $(125 \mathrm{MHz}$ APT, DMSO- $d_{6}$ ) $\delta 101.7,121.2,121.8,124.2,124.9,125.7$, 127.3, 127.5, 128.5, 128.8, 129.0, 130.1, 131.4, 132.1, 132.4, 133.9, 134.0, 134.4, 134,8, 136.7, 145.8, 181.1, 182.0; HRESIMS $m / z$, calcd. for $\mathrm{C}_{26} \mathrm{H}_{17} \mathrm{~N}_{2} \mathrm{O}_{4} \mathrm{~S}^{-}[\mathrm{M}-\mathrm{H}]^{-}$: 453.0915, found: 453.0916 .

$N$-(4-((1,4-Dioxo-1,4-dihydronaphthalen-2-yl)amino) phenyl)-4-fluorobenzenesulfonamide (8d)

Dark brown solid; yield $>99 \%(418 \mathrm{mg}) ; \mathrm{mp} 210-212{ }^{\circ} \mathrm{C}$; IR $(\mathrm{KBr}) \vee / \mathrm{cm}^{-1} 724,829,923,1153,1347,1406,1594$, 1669,$3107 ;{ }^{1} \mathrm{H}$ NMR $\left(500 \mathrm{MHz}, \mathrm{DMSO}-d_{6}\right) \delta 5.99(\mathrm{~s}, 1 \mathrm{H})$, $7.16(\mathrm{~d}, 2 \mathrm{H}, J 8.8 \mathrm{~Hz}), 7.27(\mathrm{~d}, 2 \mathrm{H}, J 8.8 \mathrm{~Hz}), 7.38(\mathrm{t}, 2 \mathrm{H}$, $J 8.8 \mathrm{~Hz}), 7.76(\mathrm{td}, 1 \mathrm{H}, J 1.3$ and $7.5 \mathrm{~Hz}), 7.82-7.86(\mathrm{~m}$, $3 \mathrm{H}), 7.95(\mathrm{dd}, 1 \mathrm{H}, J 1.0$ and $7.7 \mathrm{~Hz}), 8.04(\mathrm{dd}, 1 \mathrm{H}, J 1.1$ and $7.7 \mathrm{~Hz}), 8.94(\mathrm{~s}, 1 \mathrm{H}), 10.20(\mathrm{~s}, 1 \mathrm{H}) ;{ }^{13} \mathrm{C} \mathrm{NMR}(125 \mathrm{MHz}$ APT, DMSO- $\left.d_{6}\right) \delta 101.9,116.1(\mathrm{~d}, J 23.0 \mathrm{~Hz}), 124.2,125.0$, 125.7, 129.4 (d, $J 10.0 \mathrm{~Hz}), 130.2,132.2,132.4,134.3$, $134.5,135.8(\mathrm{~d}, J 3.0 \mathrm{~Hz}), 145.9,164.1(\mathrm{~d}, J 245.0 \mathrm{~Hz})$, 181.2, 182.2; HRESIMS $m / z$, calcd. for $\mathrm{C}_{22} \mathrm{H}_{15} \mathrm{FN}_{2} \mathrm{NaO}_{4} \mathrm{~S}^{+}$ $[\mathrm{M}+\mathrm{Na}]^{+}:$445.0629, found: 445.0615 .

$N$-(4-((1,4-Dioxo-1,4-dihydronaphthalen-2-yl)amino) phenyl)-4-nitrobenzenesulfonamide (8e)

Dark red solid; yield $>99 \%(445 \mathrm{mg}) ; \mathrm{mp}>\mathrm{d} 210{ }^{\circ} \mathrm{C}$; IR (KBr) $v / \mathrm{cm}^{-1} 740,854,1194,1347,1624,1667,3104$; ${ }^{1} \mathrm{H}$ NMR (500 MHz, DMSO- $\left.d_{6}\right) \delta 6.01(\mathrm{~s}, 1 \mathrm{H}), 7.17(\mathrm{~d}, 1 \mathrm{H}$, $J 8.8 \mathrm{~Hz}), 7.29(\mathrm{~d}, 1 \mathrm{H}, J 8.8 \mathrm{~Hz}), 7.76(\mathrm{td}, J 1.4$ and $7.5 \mathrm{~Hz})$, $7.84(\mathrm{td}, 1 \mathrm{H}, J 1.4$ and $7.5 \mathrm{~Hz}), 7.94(\mathrm{ddd}, 1 \mathrm{H}, J 0.4,1.4$ and $7.6 \mathrm{~Hz}), 8.01-8.05(\mathrm{~m}, 2 \mathrm{H}), 8.37(\mathrm{~d}, 2 \mathrm{H}, J 9.0 \mathrm{~Hz}), 8.95(\mathrm{~s}$, $1 \mathrm{H}), 10.50(\mathrm{~s}, 1 \mathrm{H}) ;{ }^{13} \mathrm{C}$ NMR $\left(125 \mathrm{MHz}\right.$ APT, DMSO- $\left.d_{6}\right)$ $\delta$ 102.0, 121.8, 124.2, 124.2, 125.7, 128.0, 130.2, 132.2, 132.4, 133.6, 134.5, 134.8, 144.9, 145.7, 149.7, 181.2, 182.1; HRESIMS $m / z$, calcd. for $\mathrm{C}_{22} \mathrm{H}_{14} \mathrm{~N}_{3} \mathrm{O}_{6} \mathrm{~S}^{-}[\mathrm{M}-\mathrm{H}]^{-}$: 448.0609, found: 448.0626 .

$N$-(4-((3-Chloro-1,4-dioxo-1,4-dihydronaphthalen-2-yl) amino)phenyl)benzenesulfonamide (9a)

Orange solid; yield > 99\% (434 mg); $\mathrm{mp} 239-241{ }^{\circ} \mathrm{C}$; IR $(\mathrm{KBr}) \vee / \mathrm{cm}^{-1} 750,843,914,1155,1296,1331,1465$, 1634, 1677, 3248; ${ }^{1} \mathrm{H}$ NMR (500 MHz, DMSO- $\left.d_{6}\right) \delta 7.01$ $(\mathrm{m}, 4 \mathrm{H}), 7.51-7.55(\mathrm{~m}, 2 \mathrm{H}), 7.59-7.61(\mathrm{~m}, 1 \mathrm{H}), 7.73-7.75$ $(\mathrm{m}, 2 \mathrm{H}), 7.78(\mathrm{td}, 1 \mathrm{H}, J 1.1$ and $7.5 \mathrm{~Hz}), 7.85(\mathrm{td}, 1 \mathrm{H}, J 1.1$ 
and 7.5 Hz), 8.00-8.03 (m, 2H), $9.01(\mathrm{~s}, 1 \mathrm{H}), 10.02(\mathrm{~s}, 1 \mathrm{H})$; ${ }^{13} \mathrm{C}$ NMR (125 MHz APT, DMSO- $d_{6}$ ) $\delta 114.1,120.7,125.3$, 126.3, 126.7, 126.9, 129.2, 130.2, 132.1, 133.1, 133.4, 134.3, 135.0, 135.5, 139.5, 143.4, 176.9, 180.2; HRESIMS $m / z$, calcd. for $\mathrm{C}_{22} \mathrm{H}_{15} \mathrm{ClN}_{2} \mathrm{NaO}_{4} \mathrm{~S}^{+}[\mathrm{M}+\mathrm{Na}]^{+}: 461.0333$, found: 461.0312 .

$N$-(4-((3-Chloro-1,4-dioxo-1,4-dihydronaphthalen-2-yl) amino)phenyl)-4-methylbenzenesulfonamide (9b)

Deep red solid; yield $>99 \%(448 \mathrm{mg}) ; \mathrm{mp} 172-174{ }^{\circ} \mathrm{C}$; IR (KBr) $v / \mathrm{cm}^{-1} 738,809,915,1157,1220,1329,1491$, 1640, 1673, 3231; ${ }^{1} \mathrm{H}$ NMR (500 MHz, DMSO- $d_{6}$ ) $\delta 2.35$ (s, 3H), $7.03(\mathrm{~s}, 4 \mathrm{H}), 7.33(\mathrm{~d}, J 8.0 \mathrm{~Hz}), 7.62(\mathrm{~d}, J 8.3 \mathrm{~Hz})$, $7.78(\mathrm{td}, 1 \mathrm{H}, J 1.3$ and $7.5 \mathrm{~Hz}), 7.85(\mathrm{td}, 1 \mathrm{H}, J 1.2$ and $7.5 \mathrm{~Hz}), 8.00-8.03(\mathrm{~m}, 2 \mathrm{H}), 9.01(\mathrm{~s}, 1 \mathrm{H}), 9.96(\mathrm{~s}, 1 \mathrm{H})$; ${ }^{13} \mathrm{C}$ NMR $\left(125 \mathrm{MHz}\right.$ APT, DMSO- $d_{6}$ ) $\delta 20.7,113.7,120.3$, $124.8,125.9,126.3,126.5,129.3,130.0,131.8,132.9$, 134.3, 134.6, 135.1, 136.6, 142.9, 143.0, 176.3, 179.7; HRESIMS $\mathrm{m} / z$, calcd. for $\mathrm{C}_{23} \mathrm{H}_{17} \mathrm{ClN}_{2} \mathrm{NaO}_{4} \mathrm{~S}^{+}[\mathrm{M}+\mathrm{Na}]^{+}$: 475.0490, found: 475.0479 .

$N$-(4-((3-Chloro-1,4-dioxo-1,4-dihydronaphthalen-2-yl) amino)phenyl)naphthalene-2-sulfonamide (9c)

Dark red solid; yield > 99\% (484 mg); $\mathrm{mp} 211-213{ }^{\circ} \mathrm{C}$; IR (KBr) v / $\mathrm{cm}^{-1} 751,822,913,1155,1291,1332,1494$, 1636, 1674, 3234; ${ }^{1} \mathrm{H}$ NMR (500 MHz, DMSO- $d_{6}$ ) $\delta 6.97$ $(\mathrm{d}, 2 \mathrm{H}, J 8.8 \mathrm{~Hz}), 7.05(\mathrm{~d}, 2 \mathrm{H}, J 8.8 \mathrm{~Hz}), 7.62-7.70(\mathrm{~m}, 2 \mathrm{H})$, 7.75-7.79 (m, $2 \mathrm{H}), 7.84(\mathrm{td}, 1 \mathrm{H}, J 1.3$ and 7.5 Hz), 7.98-8.01 $(\mathrm{m}, 3 \mathrm{H}), 8.06-8.09(\mathrm{~m}, 2 \mathrm{H}), 8.37(\mathrm{~d}, 1 \mathrm{H}, J 1.5 \mathrm{~Hz}), 8.98(\mathrm{~s}$, $1 \mathrm{H}), 10.13(\mathrm{~s}, 1 \mathrm{H}) ;{ }^{13} \mathrm{C}$ NMR (125 MHz APT, DMSO- $\left.d_{6}\right)$ $\delta$ 113.7. 121.9, 124.7, 125.8, 126.1, 127.3, 127.5, 127.6, 128.5, 128.9, 128.9, 129.9, 131.3, 131.7, 132.8, 134.0, 134.5, 135.2, 136.5, 142.9, 176.2, 179.7; HRESIMS $\mathrm{m} / z$, $[\mathrm{M}-\mathrm{H}]^{-}$calcd. for $\mathrm{C}_{26} \mathrm{H}_{16} \mathrm{ClN}_{2} \mathrm{O}_{4} \mathrm{~S}^{-}: 487.0525$, found: 487.0526 .

$\mathrm{N}$-(4-((3-Chloro-1,4-dioxo-1,4-dihydronaphthalen-2-yl) amino)phenyl)-4-fluorobenzenesulfonamide (9d)

Brown solid; yield $>99 \%$ (452 mg); $\mathrm{mp} 173-175^{\circ} \mathrm{C}$; IR (KBr) $v / \mathrm{cm}^{-1} 790,838,916,1165,1236,1379,1430,1669$, 3246; ' ${ }^{\mathrm{H}} \mathrm{NMR}\left(500 \mathrm{MHz}\right.$, DMSO- $\left.d_{6}\right) \delta$ 7.00-7.03 (m, 4H), 7.33-7.38 (m, 2H), 7.76-7.80 (m, 3H), 7.85 (td, 1H, $J 1.1$ and $7.7 \mathrm{~Hz}), 8.02(\mathrm{dd}, 1 \mathrm{H}, J 1.1$ and $7.7 \mathrm{~Hz}), 9.02(\mathrm{~s}, 1 \mathrm{H})$, $10.04(\mathrm{~s}, 1 \mathrm{H}) ;{ }^{13} \mathrm{C}$ NMR $\left(125 \mathrm{MHz}\right.$ APT, DMSO- $\left.d_{6}\right) \delta 113.8$, 115.9 (d, J $22.7 \mathrm{~Hz}), 120.5,124.8,125.8,126.2,129.5$ (d, $J 10.0 \mathrm{~Hz}), 129.9,131.8,132.8,133.8,134.5,135.4,135.7$ (d, J 3.0 Hz), 142.9, 164.0 (d, J 253.0 Hz), 176.2, 179.7; HRESIMS $m / z$, calcd. for $\mathrm{C}_{22} \mathrm{H}_{14} \mathrm{ClFN}_{2} \mathrm{NaO}_{4} \mathrm{~S}^{+}[\mathrm{M}+\mathrm{Na}]^{+}$: 479.0239, found: 479.0220 .
$N$-(4-((3-Chloro-1,4-dioxo-1,4-dihydronaphthalen-2-yl) amino)phenyl)-4-nitrobenzenesulfonamide (9e)

Yield $>99 \%$ ( $479 \mathrm{mg}$ ); deep brown solid; $\mathrm{mp} 223-225^{\circ} \mathrm{C}$; IR (KBr) v / $\mathrm{cm}^{-1} 737,847,1159,1257,1379,1491,1598$, 1699, 2918, 3103, 3239; ${ }^{1} \mathrm{H}$ NMR (500 MHz, DMSO- $d_{6}$ ) $\delta 7.03(\mathrm{~s}, 4 \mathrm{H}), 7.79(\mathrm{td}, 1 \mathrm{H}, J 1.3$ and $7.5 \mathrm{~Hz}), 7.85(\mathrm{td}$, $1 \mathrm{H}, J 1.3$ and $7.5 \mathrm{~Hz}), 7.98(\mathrm{~d}, 2 \mathrm{H}, J 8.9 \mathrm{~Hz}), 8.01-8.03$ $(\mathrm{m}, 2 \mathrm{H}), 8.36(\mathrm{~d}, 2 \mathrm{H}, J 8.9 \mathrm{~Hz}), 9.04(\mathrm{~s}, 1 \mathrm{H}), 10.36(\mathrm{~s}, 1 \mathrm{H})$; ${ }^{13} \mathrm{C}$ NMR (125 MHz APT, DMSO- $\left.d_{6}\right) \delta 114.3,121.0,124.1$, 124.7, 125.8, 126.2, 128.1, 130.0, 131.7, 132.8, 133.0, 134.5, 135.9, 142.8, 144.8, 149.6, 176.3, 179.6; HRESIMS $\mathrm{m} / z$, calcd. for $\mathrm{C}_{22} \mathrm{H}_{13} \mathrm{ClN}_{3} \mathrm{O}_{6} \mathrm{~S}^{+}[\mathrm{M}-\mathrm{H}]^{+}: 482.0219$, found: 482.0229 .

$\mathrm{N}$-(3-((3-Chloro-1,4-dioxo-1,4-dihydronaphthalen-2-yl) amino)phenyl)benzenesulfonamide (10a)

Yield 55\% (241 mg); deep brown solid; $\mathrm{mp}$ 244$246{ }^{\circ} \mathrm{C}$; IR (KBr) $v / \mathrm{cm}^{-1} 726,842,1330,1638,1677$, 3244; ${ }^{1} \mathrm{H}$ NMR (500 MHz, DMSO- $d_{6}$ ) $\delta 10.13$ (s, 1H), 9.09 $(\mathrm{s}, 1 \mathrm{H}), 8.04(\mathrm{dd}, 1 \mathrm{H}, J 1.5$ and $8.0 \mathrm{~Hz}), 8.01$ (dd, $1 \mathrm{H}, J 1.5$ and $8.0 \mathrm{~Hz}), 7.86(\mathrm{td}, 1 \mathrm{H}, J 1.4$ and $7.5 \mathrm{~Hz}), 7.76-7.82(\mathrm{~m}$, $3 \mathrm{H}), 7.58-7.61(\mathrm{~m}, 1 \mathrm{H}), 7.51-7.54(\mathrm{~m}, 2 \mathrm{H}), 7.14(\mathrm{t}, 1 \mathrm{H}$, $J 8.0 \mathrm{~Hz}), 6.87-6.90(\mathrm{~m}, 2 \mathrm{H}), 6.80-6.82(\mathrm{~m}, 1 \mathrm{H}) ;{ }^{13} \mathrm{C} \mathrm{NMR}$ $\left(125 \mathrm{MHz}\right.$ APT, DMSO- $\left.d_{6}\right) \delta$ 115.0, 115.5, 116.0, 119.6, $125.8,126.2,126.3,128.2,128.8,130.0,131.6,132.5$, 132.9, 134.4, 137.4, 139.5, 139.6, 142.9, 176.3, 179.6; HRESIMS $m / z$, calcd. for $\mathrm{C}_{22} \mathrm{H}_{15} \mathrm{ClN}_{2} \mathrm{NaO}_{4} \mathrm{~S}^{+}[\mathrm{M}+\mathrm{Na}]^{+}$: 461.0333, found 461.0334 .

$\mathrm{N}$-(3-((3-Chloro-1,4-dioxo-1,4-dihydronaphthalen-2-yl) amino)phenyl)-4-methylbenzenesulfonamide (10b)

Yield 77\% (348 mg); red solid; $\mathrm{mp} 137-139{ }^{\circ} \mathrm{C}$; IR (KBr) $\vee / \mathrm{cm}^{-1}$ 717, 842, 1153, 1330, 1646, 1673, 3286; ${ }^{1} \mathrm{H}$ NMR $\left(500 \mathrm{MHz}\right.$, DMSO- $\left.d_{6}\right) \delta 10.05(\mathrm{~s}, 1 \mathrm{H}), 9.08$ (s, $1 \mathrm{H}), 8.04(\mathrm{dd}, 1 \mathrm{H}, J 0.5$ and $7.5 \mathrm{~Hz}), 8.02(\mathrm{dd}, 1 \mathrm{H}, J 0.5$ and $7.5 \mathrm{~Hz}), 7.87(\mathrm{td}, 1 \mathrm{H}, J 1.5$ and $7.5 \mathrm{~Hz}), 7.86(\mathrm{td}$, $1 \mathrm{H}, J 1.5$ and $7.5 \mathrm{~Hz}), 7.65(\mathrm{~d}, 2 \mathrm{H}, J 8.5 \mathrm{~Hz}), 7.32(\mathrm{~d}$, $2 \mathrm{H}, J 8.5 \mathrm{~Hz}), 7.14(\mathrm{t}, 1 \mathrm{H}, J 8.0 \mathrm{~Hz}), 6.88-6.87(\mathrm{~m}, 2 \mathrm{H})$, 6.81-6.80 (m, 1H), $2.33(\mathrm{~s}, 3 \mathrm{H}) ;{ }^{13} \mathrm{C}$ NMR $(125 \mathrm{MHz}$ APT, DMSO- $\left.d_{6}\right) \delta 20.6,115.0,115.4,115.9,119.5$, $125.8,126.2,128.2,126.4,129.2,130.0,131.6,132.9$, 134.4, 136.8, 137.5, 139.5, 142.8, 142.9, 176.3, 179.6; HRESIMS $m / z$, calcd. for $\mathrm{C}_{23} \mathrm{H}_{17} \mathrm{ClN}_{2} \mathrm{NaO}_{4} \mathrm{~S}^{+}[\mathrm{M}+\mathrm{Na}]^{+}$: 475.0490, found 475.0461 .

$\mathrm{N}$-(3-((3-Chloro-1,4-dioxo-1,4-dihydronaphthalen-2-yl) amino)phenyl)naphthalene-2-sulfonamide (10c)

Yield 70\% (342 mg); deep brown solid; mp 240$242{ }^{\circ} \mathrm{C}$; IR $(\mathrm{KBr}) \vee / \mathrm{cm}^{-1} 748,844,1151,1330,1593$, 1675,3213 ; ${ }^{1} \mathrm{H}$ NMR $\left(500 \mathrm{MHz}, \mathrm{DMSO}-d_{6}\right) \delta$ 6 6.77-6.79 $(\mathrm{m}, 1 \mathrm{H}), 6.90-6.92(\mathrm{~m}, 1 \mathrm{H}), 6.94-6.95(\mathrm{~m}, 1 \mathrm{H}), 7.12(\mathrm{t}, 1 \mathrm{H}$, 
$J 8.0 \mathrm{~Hz}), 7.62-7.65(\mathrm{~m}, 1 \mathrm{H}), 7.66-7.70(\mathrm{~m}, 1 \mathrm{H}), 7.77-7.81$ $(\mathrm{m}, 2 \mathrm{H}), 7.86(\mathrm{td}, 1 \mathrm{H}, J 1.4$ and $7.5 \mathrm{~Hz}), 7.97-8.00(\mathrm{~m}, 2 \mathrm{H})$, $8.03(\mathrm{dd}, 1 \mathrm{H}, J 1.0$ and $7.6 \mathrm{~Hz}), 8.05-8.07(\mathrm{~m}, 2 \mathrm{H}), 8.41$ $(\mathrm{d}, 1 \mathrm{H}, J 1.5 \mathrm{~Hz}), 9.06(\mathrm{~s}, 1 \mathrm{H}), 10.22(\mathrm{~s}, 1 \mathrm{H}) ;{ }^{13} \mathrm{C} \mathrm{NMR}$ $\left(125 \mathrm{MHz}\right.$ APT, DMSO- $d_{6}$ ) $\delta 115.0,115.6,116.0,119.6$, $121.8,125.8,126.2,127.0,127.5,127.6,128.2,128.5$, $128.8,129.0,130.0,131.3,131.6,132.9,134.0,134.4$, 136.6, 137.4, 139.5, 142.9, 176.3, 179.5; HRESIMS $\mathrm{m} / \mathrm{z}$, calcd. for $\mathrm{C}_{26} \mathrm{H}_{17} \mathrm{ClN}_{2} \mathrm{NaO}_{4} \mathrm{~S}^{+}[\mathrm{M}+\mathrm{Na}]^{+}: 511.0490$, found: 511.0495 .

$N$-(3-((3-Chloro-1,4-dioxo-1,4-dihydronaphthalen-2-yl) amino)phenyl)-4-nitrobenzenesulfonamide (10d)

Yield 45\% (218 mg); brown solid; mp 204-206 ${ }^{\circ} \mathrm{C}$; IR $(\mathrm{KBr}) \vee / \mathrm{cm}^{-1} 734,850,1154,1343,1594,1676,3182$; ${ }^{1} \mathrm{H}$ NMR (500 MHz, DMSO- $\left.d_{6}\right) \delta 6.86-6.88(\mathrm{~m}, 2 \mathrm{H}), 6.89-$ $6.91(\mathrm{~m}, 1 \mathrm{H}), 7.19(\mathrm{t}, 1 \mathrm{H}, J 8.0 \mathrm{~Hz}), 7.80(\mathrm{td}, 1 \mathrm{H}, J 1.5$ and $7.5 \mathrm{~Hz}), 7.87(\mathrm{td}, 1 \mathrm{H}, J 1.5$ and $7.5 \mathrm{~Hz}), 8.00(\mathrm{~s}, 4 \mathrm{H}), 8.35$ $(\mathrm{d}, 2 \mathrm{H}, J 9.0 \mathrm{~Hz}), 9.10(\mathrm{~s}, 1 \mathrm{H}), 10.47(\mathrm{~s}, 1 \mathrm{H}) ;{ }^{13} \mathrm{C} \mathrm{NMR}$ (125 MHz APT, DMSO- $d_{6}$ ) $\delta 115.1,115.9,116.5,120.1$, $124.2,125.8,126.2,128.0,128.4,130.0,131.6,132.9$, 134.4, 136.5, 139.6, 142.9, 144.9, 149.7, 176.3, 179.6; HRESIMS $m / z$, calcd. for $\mathrm{C}_{22} \mathrm{H}_{14} \mathrm{ClN}_{3} \mathrm{NaO}_{6} \mathrm{~S}^{+}[\mathrm{M}+\mathrm{Na}]^{+}$: 506.0184, found: 506.0152 .

\section{General procedure for 11a-11e preparation}

A stirred solution of $7 \mathbf{d}(100 \mathrm{mg} ; 0.540 \mathrm{mmol})$ in $5 \mathrm{~mL}$ of acetonitrile was cooled in an ice bath, and $2.16 \mathrm{mmol}$ of the appropriate sulfonyl chloride was added. Subsequently, trimethylamine $(1.6 \mathrm{mmol})$ was added to the reaction mixture, and the ice bath was removed. The reaction occurred at room temperature for an additional $1 \mathrm{~h}$. After the starting material total consumption, the reaction mixture was poured into $25 \mathrm{~mL}$ of water and extracted using ethyl acetate $(3 \times 50 \mathrm{~mL})$. The organic phase was washed with brine $(3 \times 50 \mathrm{~mL})$, dried with anhydrous sodium sulfate, filtered, and evaporated under reduced pressure. The mixture was purified by column chromatography on silicagel using a gradient mixture of hexane/ethyl acetate as eluent to obtain the pure derivatives.

7-Amino-5,8-dioxo-5,8-dihydronaphthalen-1-ylbenzenesulfonate (11a)

Orange solid; yield 95\% (169 mg); mp 216-217 ${ }^{\circ} \mathrm{C}$; IR (KBr) $v / \mathrm{cm}^{-1} 694,755,829,1142,1350,1614,1686$, $3462 ;{ }^{1} \mathrm{H}$ NMR $\left(500 \mathrm{MHz}\right.$, DMSO- $\left.d_{6}\right) \delta 7.94$ (dd, $1 \mathrm{H}, J 1.2$ and $7.7 \mathrm{~Hz}), 7.88(\mathrm{dd}, 2 \mathrm{H}, J 1.2$ and $8.4 \mathrm{~Hz}), 7.83-7.78(\mathrm{~m}$, $2 \mathrm{H}), 7.66(\mathrm{dd}, 2 \mathrm{H}, J 7.6$ and 8.4), $7.27(\mathrm{dd}, 1 \mathrm{H}, J 1.2$ and $8.2 \mathrm{~Hz}), 7.06$ (s, 2H), $5.80(\mathrm{~s}, 1 \mathrm{H}) ;{ }^{13} \mathrm{C}$ NMR $(125 \mathrm{MHz}$ APT, DMSO- $\left.d_{6}\right) \delta 101.1,122.8,124.4,126.6,128.0,129.3$, 134.6, 134.7, 135.2, 135.2, 146.0, 150.6, 179.0, 179.7;
HRESIMS $\mathrm{m} / \mathrm{z}$, calcd. for $\mathrm{C}_{16} \mathrm{H}_{11} \mathrm{NNaO}_{5} \mathrm{~S}^{+}[\mathrm{M}+\mathrm{Na}]^{+}$: 352.0250, found: 352.0252 .

7-Amino-5,8-dioxo-5,8-dihydronaphthalen-1-yl-4-methylbenzenesulfonate (11b)

Orange solid; yield $>99 \%(183 \mathrm{mg}) ; \mathrm{mp} 210-211{ }^{\circ} \mathrm{C}$; IR (KBr) $v / \mathrm{cm}^{-1}$ 694, 829, 1350, 1615, 1686, 3346, 3465; ${ }^{1} \mathrm{H}$ NMR (500 MHz, DMSO- $\left.d_{6}\right) \delta 2.42(\mathrm{~s}, 3 \mathrm{H}), 5.80(\mathrm{~s}$, $1 \mathrm{H}), 7.05(\mathrm{~s}, 2 \mathrm{H}), 7.27(\mathrm{dd}, 1 \mathrm{H}, J 0.7$ and $8.2 \mathrm{~Hz}), 7.46(\mathrm{~d}$, $2 \mathrm{H}, J 8.5 \mathrm{~Hz}), 7.74$ (d, 2H, J 8.4 Hz), 7.77-7.80 (m, 1H), $7.93(\mathrm{dd}, 1 \mathrm{H}, J 1.1$ and $7.7 \mathrm{~Hz}) ;{ }^{13} \mathrm{C}$ NMR $(125 \mathrm{MHz}$ APT, DMSO- $\left.d_{6}\right) \delta 20.8,101.1,122.9,124.3,126.6,128.0,129.7$, 131.7, 135.1, 135.2, 145.6, 146.1, 150.6, 179.0, 179.4; HRESIMS $m / z$, calcd. for $\mathrm{C}_{17} \mathrm{H}_{13} \mathrm{NNaO}_{5} \mathrm{~S}^{+}[\mathrm{M}+\mathrm{Na}]^{+}$: 366.0407, found: 366.0389 .

7-Amino-5,8-dioxo-5,8-dihydronaphthalen-1-ylnaphthalene2-sulfonate (11c)

Orange solid; yield $>99 \%(203 \mathrm{mg}) ; \mathrm{mp} 230-231^{\circ} \mathrm{C}$; IR (KBr) v / $\mathrm{cm}^{-1}$ 696, 827, 1354, 1616, 1689, 3350; ${ }^{1} \mathrm{H}$ NMR $\left(300 \mathrm{MHz}\right.$, DMSO- $\left.d_{6}\right) \delta 5.78(\mathrm{~s}, 1 \mathrm{H}), 7.05(\mathrm{~s}$, $2 \mathrm{H}), 7.22-7.24(\mathrm{~m}, 1 \mathrm{H}), 7.68-7.81(\mathrm{~m}, 3 \mathrm{H}), 7.88-7.94$ $(\mathrm{m}, 2 \mathrm{H}), 8.09-8.11(\mathrm{~m}, 1 \mathrm{H}), 8.19-8.21(\mathrm{~m}, 2 \mathrm{H}), 8.57$ $(\mathrm{d}, 1 \mathrm{H}, J 1.3 \mathrm{~Hz}) ;{ }^{13} \mathrm{C}$ NMR $\left(125 \mathrm{MHz}\right.$ APT, DMSO- $\left.d_{6}\right)$ $\delta$ 101.3, 122.3, 122.9, 124.4, 126.6, 127.7, 127.7, 129.3, $129.5,129.6,129.9,131.2,131.8,134.9,135.2,135.2$, 146.1, 150.6, 179.1, 179.6; HRESIMS $\mathrm{m} / \mathrm{z}$, calcd. for $\mathrm{C}_{20} \mathrm{H}_{13} \mathrm{NNaO}_{5} \mathrm{~S}^{+}[\mathrm{M}+\mathrm{Na}]^{+}:$: 402.0407, found: 402.0405 .

7-Amino-5,8-dioxo-5,8-dihydronaphthalen-1-yl-4-fluorobenzenesulfonate (11d)

Orange solid; yield $98 \%$ (184 mg); mp 207-208 ${ }^{\circ} \mathrm{C}$; IR (KBr) $v / \mathrm{cm}^{-1} 696,826,1355,1615,1688,3350 ;{ }^{1} \mathrm{H}$ NMR $\left(300 \mathrm{MHz}\right.$, DMSO- $\left.d_{6}\right) \delta 5.81(\mathrm{~s}, 1 \mathrm{H}), 7.05(\mathrm{~s}, 2 \mathrm{H}), 7.31$ (dd, $1 \mathrm{H}, J 1.2$ and $8.2 \mathrm{~Hz}), 7.45-7.51(\mathrm{~m}, 2 \mathrm{H}), 7.78-7.83$ (m, 1H), 7.92-7.97 (m, 3H); ${ }^{13} \mathrm{C}$ NMR (125 MHz APT, DMSO- $\left.d_{6}\right) \delta 101.9,117.4(\mathrm{~d}, J 23.0 \mathrm{~Hz}), 123.6,125.3$, $127.5,131.6(\mathrm{~d}, J 3.0 \mathrm{~Hz}), 132.1(\mathrm{~d}, J 10.0 \mathrm{~Hz}), 136.0$, 136.0, 146.6, 151.4, 166.1 (d, J 253.0 Hz), 179.8, 180.4; HRESIMS $m / z$ calcd. for $\mathrm{C}_{16} \mathrm{H}_{10} \mathrm{FNNaO}_{5} \mathrm{~S}^{+}[\mathrm{M}+\mathrm{H}]^{+}$: 370.0156; found: 370.0154 .

7-Amino-5,8-dioxo-5,8-dihydronaphthalen-1-yl4-nitrobenzenesulfonate (11e)

Orange solid; yield 98\% (198 mg); mp 213-214 ${ }^{\circ} \mathrm{C}$; IR (KBr) $v / \mathrm{cm}^{-1} 740,763,832,1348,1618,1682,3364$; ${ }^{1} \mathrm{H}$ NMR $\left(500 \mathrm{MHz}\right.$, DMSO- $\left.d_{6}\right) \delta 5.81(\mathrm{~s}, 1 \mathrm{H}), 7.06(\mathrm{~s}, 2 \mathrm{H})$, $7.31(\mathrm{dd}, 1 \mathrm{H}, J 1.2$ and $8.1 \mathrm{~Hz}), 7.80-7.83(\mathrm{~m}, 1 \mathrm{H}), 7.98(\mathrm{dd}$, $1 \mathrm{H}, J 1.2$ and $7.7 \mathrm{~Hz}), 8.16(\mathrm{~d}, 2 \mathrm{H}, J 9.0 \mathrm{~Hz}), 8.45(\mathrm{~d}, 2 \mathrm{H}$, $J 9.0 \mathrm{~Hz}) ;{ }^{13} \mathrm{C}$ NMR $\left(125 \mathrm{MHz}\right.$ APT, DMSO- $\left.d_{6}\right) \delta 101.2$, $122.7,124.5,124.8,126.8,129.7,135.3,135.5,140.0$, 
145.6, 150.6, 150.9, 179.1, 179.6; HRESIMS m/z, calcd. for $\mathrm{C}_{16} \mathrm{H}_{10} \mathrm{~N}_{2} \mathrm{NaO}_{7} \mathrm{~S}^{+}[\mathrm{M}+\mathrm{Na}]^{+}$: 397.0101, found: 397.0086 .

\section{Biological assays}

\section{Cells and virus}

Vero cells (African green monkey kidney) Vero-ATCC CCL81 were cultivated in modified Dulbecco medium (DMEM, cat. No 11960, Invitrogen, São Paulo, Brazil), with routine supplementation with $5 \%$ fetal bovine serum (FBS; Invitrogen, São Paulo, Brazil), and two $\mathrm{mmol} \mathrm{L}^{-1}$ L-glutamine (cat 25030, Invitrogen, São Paulo, Brazil). Antibiotics were added, reaching a final concentration of 50 units $\mathrm{mL}^{-1}$ penicillin and streptomycin (cat. No. 15070, Invitrogen, São Paulo, Brazil). The Chikungunya virus used was isolated from interviewed patients who agreed with blood collection. All patients were included by signing an informed consent form, approved by the registered research ethics committee - CAAE: 61845416.0.0000.5289. After viral isolation, the sequences were deposited in GenBank under accession numbers MK910738 (BRA/RJ/1F), MK910739 (BRA/RJ/18) and MK910740 (BRA/RJ/ 23). Virus samples were amplified in Vero cells, titrated and frozen at $-70^{\circ} \mathrm{C}$ for use. For antiviral activity the strain with the deposit number MK910738 was used as it is a strain with full homology to the circulating throughout Brazil. ${ }^{27}$

\section{Effect of the compounds on the cellular viability}

The naphthoquinone derivatives cytotoxicity in Vero cells was evaluated using 3-(4,5-dimethylthiazol-2-yl)2,5-diphenyltetrazolium bromide tetrazolium (MTT) reduction colorimetric assay in 96-well plate and incubated for $24 \mathrm{~h}$ at $37^{\circ} \mathrm{C} .{ }^{28}$ After, naphthoquinones derivatives were added in increasing concentrations, ranging from 50 to $1000 \mu \mathrm{M}$, diluted in DMEM. After this period, the cells were incubated with the MTT method and evaluated in a microplate reader to determine cell viability. DMSOtreated cells (1.0\%) in DMEM were used as control of the evaluation. Determination of cell viability was calculated by percentage comparing treated cells with untreated cells and cells in DMSO.

$\mathrm{TCID}_{50}$ (median tissue culture infectious dose) assay for infectious virus

The effect of naphthoquinone derivatives on CHIKV replication was determined with a fixed dose of $20 \mu \mathrm{M}$, added to $2 \times 10^{5}$ infected Vero cells. This first step was to determine which key compounds were able to inhibit viral replication at this concentration and thus initiate studies with compounds that have a high inhibitory potential. Then, $2 \times 10^{5}$ Vero cells were plated in 24-well plate in DMEM medium with $5 \%$ fetal bovine serum (FBS) and incubated at $37{ }^{\circ} \mathrm{C}$ at $5 \% \mathrm{CO}_{2}$. After the cells reach above $90 \%$ of confluence, the antiviral evaluation is initiated. The virus inoculum was diluted to a multiplicity of infection (MOI) of 0.1 in serum-free DMEM and added for $1 \mathrm{~h}$ for adsorption of viral particles at $37^{\circ} \mathrm{C}$. Afterwards, the viral inoculum was derived, the cells were washed with phosphate buffer solution (PBS) to remove non-adsorbed viral residue and fresh medium was added at the concentration of compounds. Infected cells were also treated with culture medium containing $1 \%$ DMSO to determine residual antiviral effect and ribavirin was used as a positive control for antiviral activity. After $24 \mathrm{~h}$ of incubation at $37^{\circ} \mathrm{C}$, the culture medium was collected and the yield of infectious virus in the cell supernatant was determined by titration using the $\mathrm{TCID}_{50}$ assay on Vero cells and it was also evaluated by assay to produce viral plaques.

\section{Virucidal profile}

For the virucidal potential analysis, a mixture of $200 \mathrm{PFU}$ (plaque-forming unit) containing CHIKV plus an equivalent compounds volume was prepared, varying concentrations of 5,10 , or $20 \mu \mathrm{M} \mathrm{mL}^{-1}$ and incubated in microtiter plates for $2 \mathrm{~h}$ at $37^{\circ} \mathrm{C}$. The virus was added to Vero cells in 24-well plates for $2 \mathrm{~h}$, washed, and incubated under plate assay conditions. A virucidal effect was defined as the compounds ability to inactivate the particles, blocking infection and any subsequent cytopathic effect. All treatment conditions were compared to a virus-only control.

\section{Time-of-addition assay}

To analyze the possible viral multiplication cycle stage affected by the compounds, we conducted a study with different addition times. Vero cell monolayers were grown in 24-well plates with $90 \%$ confluence. A triplicate was treated with $10 \mu \mathrm{M}$ one hour before infection, called time -1 . After one hour, the plate was fully infected with CHIKV at an MOI of 0.1, and immediately after infection, another triplicate was treated with the compounds, called time zero or concomitant. The remaining triplicates were treated according to times 1, 2, 4, 6, $8 \mathrm{~h}$. After incubation for a further $12 \mathrm{~h}$, the culture supernatants were collected, and the cells in the culture medium were supplemented with 3\% carboxymethylcellulose. After $72 \mathrm{~h}$ of incubation at $37{ }^{\circ} \mathrm{C}$, the cells were fixed with $20 \%$ formaldehyde for $2 \mathrm{~h}$ and stained with crystal violet for $5 \mathrm{~min}$. The plaques formed after each treatment were counted, and inhibition of viral replication was determined.

\section{Molecular docking studies}

We obtained the three-dimensional structures of the potential targets of 10c and 11a from the Protein Data Bank 
(PDB) for molecular docking purposes. The structures of CHIKV proteins were obtained under the following codes: the envelope proteins E1-E2-E3 complex (PDB 3N42), ${ }^{29}$ the capsid protein $(\mathrm{PDB} 5 \mathrm{H} 23)^{30}$ protease domain, the protease (PDB 3TRK), ${ }^{31}$ and the nsP2 helicase (PDB 6JIM) ${ }^{32}$ domains, and the nsP3 (PDB 3GPO) ${ }^{33}$ macro domain. The three-dimensional structure of 10c, 11a, D9, a known nsP2 protease inhibitor, and heparitin, a known envelope proteinligand, was constructed and optimized using the Spartan'10 software (Wavefunction Inc. Irvine, CA). ${ }^{34}$

Initially, the compounds were submitted to a conformational analysis using the MMFF (Merck Molecular Force Field) force field. The lowest-energy conformer was subjected to a geometry optimization using the semi-empirical RM1 method, followed by an energy calculation using the density functional theory method with B3LYP/6-311G* basis set. The molecular docking studies were performed using Autodock Tools 1.5.7 and Autodock 4.2.6. ${ }^{35}$ Dockings of 10c and 11a into the potential targets were conducted considering the results of the experimental assays. Solvent and other artifact molecules were removed from the protein structures. Autodock Tools was used to add polar hydrogens and Gasteiger charges. Proteins were considered rigid, while total flexibility of ligands was allowed. The grid box for each protein was defined according to their binding sites described in the literature: the heparan-sulfate-binding and the predicted binding pocket 1 sites of the envelope protein, the active (comprising the catalytic triad) and the hydrophobic (where E2 protein interacts with the capsid protein) sites, the active site of nsP2 protease, the adenosine triphosphate (ATP) binding site of nsP2 helicase, and the ADP-ribose binding site of nsP3..$^{36-38}$

The Lamarckian genetic algorithm was employed, and a total of 50 binding poses were calculated for each binding site. The pose with the lowest binding energy was selected for evaluation. The potential target of 10c and 11a was elected based on the binding energy and visual inspection of the binding mode and interaction analysis compared with known ligands. These analyses were realized using the Discovery Studio Visualizer 2019 (Dassault Systèmes BIOVIA, San Diego, 2019) ${ }^{39}$ and Pymol version 2.5 (The PyMOL Molecular Graphics System, version 2.5, Schrödinger, LLC). ${ }^{40}$

\section{Statistical analysis}

The data were analyzed by one-way analysis of variance (ANOVA) followed by Tukey's post-test using the GraphPad Instat version 3 program. ${ }^{41} \mathrm{~A} p$-value of $<0.05$ was considered statistically significant.

\section{Results and Discussion}

\section{Chemistry}

The amino-naphthoquinones (7a-7d) used as starting material for the preparation of sulfonamide-based naphthoquinones derivatives were prepared according to the reported methodology. ${ }^{42,43}$ Subsequently, the desired sulfonamide derivatives (8a-8e, 9a-9e, and 10a-10d) were obtained in one step by choosing the appropriate amino-naphthoquinones (7a-7c) with various aryl sulfonyl chlorides catalyzed by DMAP in pyridine. The overall yield calculated after column chromatography purification ranged from 45-99\%. Spectroscopic techniques confirmed the structures of all final compounds (8-10). In general, the FTIR analysis of sulfonamide derivatives exhibited absorption bands at $1600-1680 \mathrm{~cm}^{-1}$, referring to the stretch vibrations of $\mathrm{C}=\mathrm{O}$ bonds. It was possible to observe absorption bands of medium intensity in the region between $3100-3300 \mathrm{~cm}^{-1}$, corresponding to the stretch vibrations of $\mathrm{N}-\mathrm{H}$ bonds. The analysis also showed absorptions at $1150-1330 \mathrm{~cm}^{-1}$, referring to asymmetric and symmetrical stretching of the $\mathrm{SO}_{2}$ group bounds. In the ${ }^{1} \mathrm{H}$ NMR of the compound $\mathbf{8 b}$, two singlets, 8.91 and 10.09 ppm were assigned to the $\mathrm{N}-\mathrm{H}$ bonds hydrogens of the sulfonamide and amino group. Regarding the naphthoquinone nucleus, it could be observed a singlet at $5.96 \mathrm{ppm}$ corresponding to $\mathrm{H}-3$ hydrogens and two double doublets at $8.03 \mathrm{ppm}$ $(\mathrm{dd}, 1 \mathrm{H}, J 7.6$ and $1.0 \mathrm{~Hz}, 1 \mathrm{H})$ and $7.94 \mathrm{ppm}(\mathrm{dd}, 1 \mathrm{H}, J 7.6$ and $1.0 \mathrm{~Hz}, 1 \mathrm{H}$ ), corresponding to typical benzoaromatic hydrogens. The other signals referring to the remaining aromatic hydrogens were observed. The other signals referring to aromatic hydrogens were observed as characteristic double signals at $7.15 \mathrm{ppm}(\mathrm{d}, 2 \mathrm{H}, J 8.9 \mathrm{~Hz}$, $2 \mathrm{H}), 7.24 \mathrm{ppm}(\mathrm{d}, 2 \mathrm{H}, J 8.9 \mathrm{~Hz}, 2 \mathrm{H}), 7.34 \mathrm{ppm}(\mathrm{d}, 2 \mathrm{H}$, $J 8.3 \mathrm{~Hz}, 2 \mathrm{H})$ and $7.66 \mathrm{ppm}(\mathrm{d}, 2 \mathrm{H}, J 8.3 \mathrm{~Hz}, 2 \mathrm{H})$.

The sulfonated naphthoquinones derivatives (11a-11e) were also prepared in a single step by treating a solution of $\mathbf{7 d}$ in acetonitrile with triethylamine (TEA) and the appropriate sulfonyl chlorides. The products were obtained with excellent yields ranging from 95-99\% (Scheme 1). Spectroscopic techniques also confirmed the chemical structures of these compounds. For example, in the ${ }^{1} \mathrm{H}$ NMR of the compound $\mathbf{1 1 b}$, it was possible to show that the sulfonylation reaction proceeded in the hydroxyl group by the absence of a characteristic signal referring to hydroxyl hydrogens. Another evidence is a singlet at $7.05 \mathrm{ppm}(\mathrm{s}, 2 \mathrm{H})$ corresponding to amino hydrogens. Besides, it is possible to observe the presence of two sets of signals referring to the aromatic hydrogens of the sulfonic ester group: two doublet signals at $7.74 \mathrm{ppm}(\mathrm{d}, 2 \mathrm{H}, J 8.4 \mathrm{~Hz}, 2 \mathrm{H})$ and 
<smiles>[R2]NC1=C([R])C(=O)c2cccc([R3])c2C1=O</smiles>

7a: $\mathrm{R}_{1}=\mathrm{H} ; \mathrm{R}_{2}=4-\mathrm{NH}_{2}-\mathrm{C}_{6} \mathrm{H}_{4} ; \mathrm{R}_{3}=\mathrm{H}$ 7b: $\mathrm{R}_{1}=\mathrm{Cl} ; \mathrm{R}_{2}=4-\mathrm{NH}_{2}-\mathrm{C}_{6} \mathrm{H}_{4} ; \mathrm{R}_{3}=\mathrm{H}$ 7c: $\mathrm{R}_{1}=\mathrm{Cl} ; \mathrm{R}_{2}=3-\mathrm{NH}_{2}-\mathrm{C}_{6} \mathrm{H}_{4} ; \mathrm{R}_{3}=\mathrm{H}$ $7 d: R_{1}=H ; R_{2}=H ; R_{3}=O H$

i) $\mathrm{RSO}_{2} \mathrm{Cl}$, DMAP, Py, rt, $24 \mathrm{~h}$ ii) $\mathrm{RSO}_{2} \mathrm{Cl}$, TEA, MeCN, 60 min

Scheme 1. Synthetic strategy to obtain naphthoquinones derivatives 8-11.<smiles>[R]C1=C(Nc2ccccc2)C(=O)c2ccccc2C1=O</smiles>

8a-8e $\left(\mathrm{R}_{1}=\mathrm{H}, 4-\mathrm{NHSO}_{2} \mathrm{R}\right)$ 8a: $\mathrm{R}=$ phenyl, $>99 \%$ 8b: $R=4$-methylphenyl, $>99 \%$ 8c: $R=$ naphthyl, $>99 \%$ 8d: $R=4$-fluorphenyl, $>99 \%$ 8e: $\mathrm{R}=4$-nitrophenyl, $>99 \%$

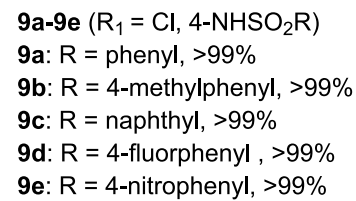

10a-10d $\left(\mathrm{R}_{1}=\mathrm{Cl}, 3-\mathrm{NHSO}_{2} \mathrm{R}\right)$

$10 \mathrm{a}: \mathrm{R}=$ phenyl, $55 \%$

10b: $R=4-$ methylphenyl, $77 \%$

10c: $R=$ naphthyl, $70 \%$

10d: $R=4$-nitrophenyl, $45 \%$

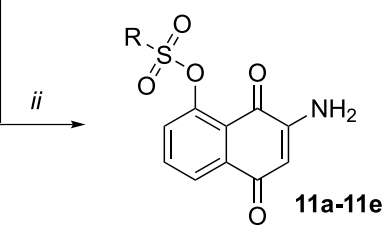

11a: $R=$ phenyl, $95 \%$

11b: $R=4-$ methylphenyl, $>99 \%$

11c: $R=$ naphthyl, $>99 \%$

11d: $R=4$-fluorphenyl, $98 \%$

11e: $R=4$-nitrophenyl, $98 \%$
$7.46 \mathrm{ppm}(\mathrm{d}, 2 \mathrm{H}, J 8.5 \mathrm{~Hz}, 2 \mathrm{H})$; and a singlet at $2.42 \mathrm{ppm}$ $(\mathrm{s}, 3 \mathrm{H})$, corresponding to a methyl group.

\section{Biological assays}

Cytotoxicity of naphthoquinone derivatives and antiviral effect

The MTT assay was used to determine the cytotoxicity of each naphthoquinone derivatives to Vero cells. The $50 \%$ cytotoxic concentration $\left(\mathrm{CC}_{50}\right)$ value of each compound was calculated (Table 1). According to our results, no high cytotoxicity was observed for all tested compounds and no cytotoxicity in cells treated with $0.1 \%$ DMSO (final solvent concentration used to dissolve naphthoquinone in the cell culture medium). After determining cytotoxicity, the compounds were used in a fixed dose $(20 \mu \mathrm{M})$ to determine whether they would be able to inhibit CHIKV replication in Vero cells. In the initial evaluation, the compounds $9 \mathrm{~b}, 9 \mathrm{e}, \mathbf{1 0 c}, \mathbf{1 1 a}$, and $11 \mathrm{~b}$ showed an inhibition effect above $98 \%$ of CHIKV replication at this fixed concentration (Table 1).

\section{Determination of the effect of naphthoquinone derivatives on CHIKV replication}

The antiviral effect evaluation was performed in Vero cells for all substances that affected greater than $90 \%$. Vero cells were infected with CHIKV using a multiplicity of infection (MOI) of 0.1 and treated for $24 \mathrm{~h}$ with increasing substances concentrations. The $\mathrm{TCID}_{50}$ method was used to titrate the virus yield, and the concentration capable of reducing the virus yield by $50 \%\left(\mathrm{EC}_{50}\right)$ was obtained from a dose-response curve, and the values are shown in Table 2 and Figure 2 . The relationship between cytotoxicity
Table 1. Cytotoxicity $\left(\mathrm{CC}_{50}\right)$ and anti-CHIKV activities at $20 \mu \mathrm{M}$ of naphthoquinone derivatives

\begin{tabular}{lcc}
\hline Compound & $\mathrm{CC}_{50} / \mu \mathrm{M}$ & $\begin{array}{c}\text { Inhibition of viral } \\
\text { replication } / \%\end{array}$ \\
\hline $\mathbf{8 a}$ & $354 \pm 3.8$ & $60 \pm 3.9$ \\
$\mathbf{8 b}$ & $201 \pm 4.6$ & $59 \pm 3.6$ \\
$\mathbf{8 d}$ & $307 \pm 5.5$ & $40 \pm 3.3$ \\
$\mathbf{8 c}$ & $449 \pm 4.7$ & $49 \pm 4.0$ \\
$\mathbf{8 e}$ & $287 \pm 5.2$ & $45 \pm 3.0$ \\
9a & $300 \pm 4.4$ & $52 \pm 2.0$ \\
9b & $281 \pm 2.5$ & $99 \pm 4.3$ \\
9d & $331 \pm 3.3$ & $80 \pm 4.2$ \\
9c & $435 \pm 3.9$ & $34 \pm 3.3$ \\
9e & $540 \pm 3.7$ & $98 \pm 3.5$ \\
10a & $399 \pm 5.5$ & $35 \pm 1.35$ \\
10b & $446 \pm 4.8$ & $23 \pm 1.5$ \\
10c & $322 \pm 6.5$ & $99 \pm 2.9$ \\
10d & $529 \pm 3.5$ & $42 \pm 3.4$ \\
11a & $352 \pm 4.3$ & $99 \pm 4.1$ \\
11b & $478 \pm 6.2$ & $99 \pm 3.9$ \\
11c & $196 \pm 4.8$ & $12 \pm 0.8$ \\
11d & $329 \pm 5.6$ & $20 \pm 1.6$ \\
11e & $233 \pm 6.8$ & $35 \pm 2.4$ \\
\hline
\end{tabular}

The mean values \pm standard deviations are representative of three independent experiments.

and the compound antiviral effect was assessed using the selectivity index (SI ratio, $\mathrm{CC}_{50} / \mathrm{EC}_{50}$ ) and determined for each molecule, obtaining unit values. As observed in Table 2, five naphthoquinone derivatives, $9 \mathbf{b}, 9 \mathrm{e}, 10 \mathrm{c}, 11 \mathbf{a}$, and 11b, showed an expressive SI for CHIKV, with 289, $457,418,400$, and 382, respectively. In the same way, in Figure 2, we can observe a dose-dependent response on the inhibitory effects obtained by the substances assessed. Ribavirin was used as a control (Table 2). 
Table 2. Cytotoxicity $\left(\mathrm{CC}_{50}\right)$, anti-CHIKV profile $\left(\mathrm{EC}_{50}\right)$ and selectivity index (SI) of naphthoquinones

\begin{tabular}{lccc}
\hline \multirow{2}{*}{ Compound } & \multicolumn{3}{c}{$\mathrm{CHIKV}$} \\
\cline { 2 - 4 } & $\mathrm{CC}_{50}{ }^{a} / \mu \mathrm{M}$ & $\mathrm{EC}_{50}{ }^{\mathrm{b}} / \mu \mathrm{M}$ & $\mathrm{SI}^{\mathrm{c}}$ \\
\hline $\mathbf{8 c}$ & $449 \pm 4.7$ & $\mathrm{ND}$ & - \\
9b & $281 \pm 2.5$ & $0.97 \pm 0.2$ & 289 \\
9d & $331 \pm 3.3$ & $3.27 \pm 0.6$ & 101 \\
9e & $540 \pm 3.7$ & $1.18 \pm 0.16$ & 457 \\
10c & $322 \pm 6.6$ & $0.77 \pm 0.1$ & 418 \\
10d & $529 \pm 3.5$ & $\mathrm{ND}$ & - \\
11a & $352 \pm 4.3$ & $0.88 \pm 0.1$ & 400 \\
11b & $478 \pm 6.2$ & $1.25 \pm 0.2$ & 382 \\
11e & $233 \pm 6.8$ & $\mathrm{ND}$ & - \\
Ribavirin & $297 \pm 4.2$ & $2.42 \pm 0.5$ & 122 \\
\hline
\end{tabular}

${ }^{a}$ Concentration that reduced $50 \%$ cytotoxic concentration when compared to untreated controls; ${ }^{\mathrm{b}}$ concentration that reduced $50 \%$ of CHIKV replication when compared to infected controls; 'selectivity index was defined as the ratio between $\mathrm{CC}_{50}$ and $\mathrm{EC}_{50}$ and represents the safety for in vitro assays. The mean values \pm standard deviations are representative of three independent experiments. CHIKV: Chikungunya virus; ND: not detected.

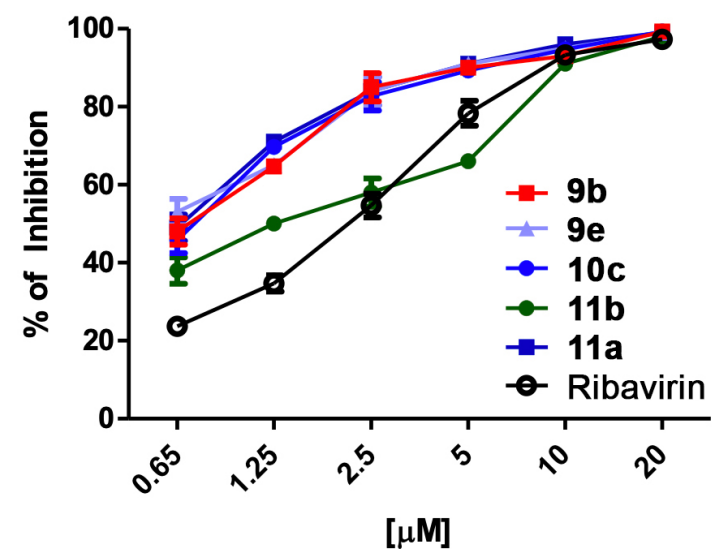

Figure 2. Inhibition of CHIKV replication by naphthoquinone derivatives and ribavirin. Vero cells were infected with CHIKV and treated at concentrations of $0.65,1.25,2.5,5,10$, and $20 \mu \mathrm{M}$. Data are presented as percentage of virus titer when compared to control cells and are expressed as the mean of three experiments \pm standard error

\section{Virucidal effect}

Given all the tested compounds, at least five derivatives exhibited a significant inhibitory profile for CHIKV replication with low cytotoxicity. A crucial step in discovering the mechanism of action is evaluating the compound's effect on the viral particle. For this reason, we determined the virucidal potential of the compounds. Our results showed that of the five compounds tested, only 11a presented some virucidal effect in the tested concentrations. As shown in Figure 3, the compound 11a was able to inhibit above 70\% in the treatment with $20 \mu \mathrm{M}$. Interestingly, ribavirin at the same concentrations did not exhibit virucidal potential.

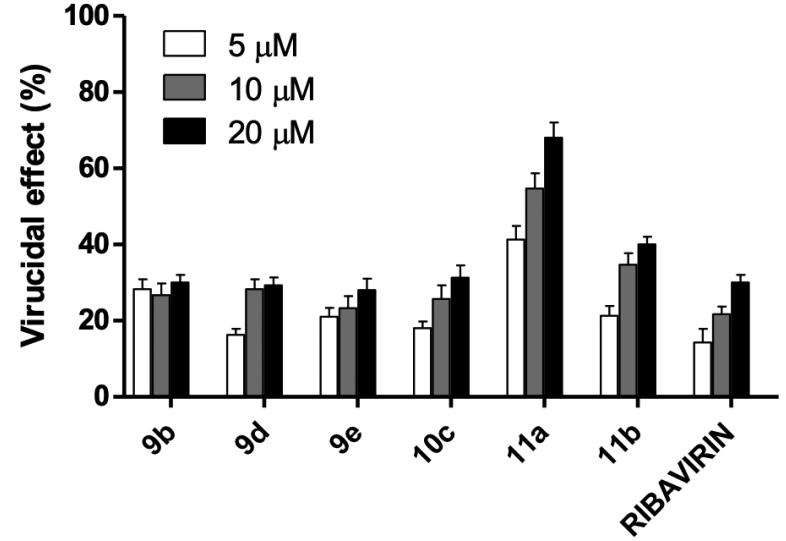

Figure 3. Naphthoquinone derivatives effect on the CHIKV infectivity. Vero cells were infected with CHIKV at an MOI of 0.1, and a plaque assay evaluated the results. Error bars indicate the standard deviation. Experiments were performed in triplicate.

\section{Time-of-addition studies}

A time-of-addition experiment was conducted to identify at which point of the CHIKV replication cycle the substances exert their specific antiviral effect. All compounds already have an antiviral effect at time 0 (concomitant) to infection, inhibiting above $90 \%$ of viral replication at the concentration used $(10 \mu \mathrm{M})$.

The substance 11a showed a differentiated profile, since, at point -1 , it presented an inhibitory potential of approximately $70 \%$, increasing its effect for up to $2 \mathrm{~h}$ post-infection, reaching inhibition above $90 \%$ at time 0 , maintaining inhibition above $80 \%$ until the second hour, declining sharply after $4 \mathrm{~h}$ post-treatment, falling below $40 \%$ inhibition. The other substances showed a greater inhibitory potential in the treatment times of 0,1 , and $2 \mathrm{~h}$, decreasing progressively after the other times, reaching an inhibitory potential below $40 \%$. Conversely, compound 10c showed low inhibitory potential at time -1 , although 0 inhibiting replication above $90 \%$, maintaining potent inhibition until $8 \mathrm{~h}$ post-infection (Figure 4). Time dependence on the inhibitory effect of compound 11a is consistent with the hypothesis that its anti-CHIKV appears to be in events before entry. The compound 10c showed an inhibitory effect with more consistent post-infection effects.

In silico prediction of the antiviral targets

\section{In silico target prediction of 10c}

According to the antiviral assays, we observed that 10c had no significant effect on the CHIKV particle infectivity but inhibited virus replication when added during attachment and later, which, in turn, indicates that this compound acts on post-entry steps. To evaluate the potential targets of this compound, we docked 10c with the available crystallographic structures of CHIKV proteins 


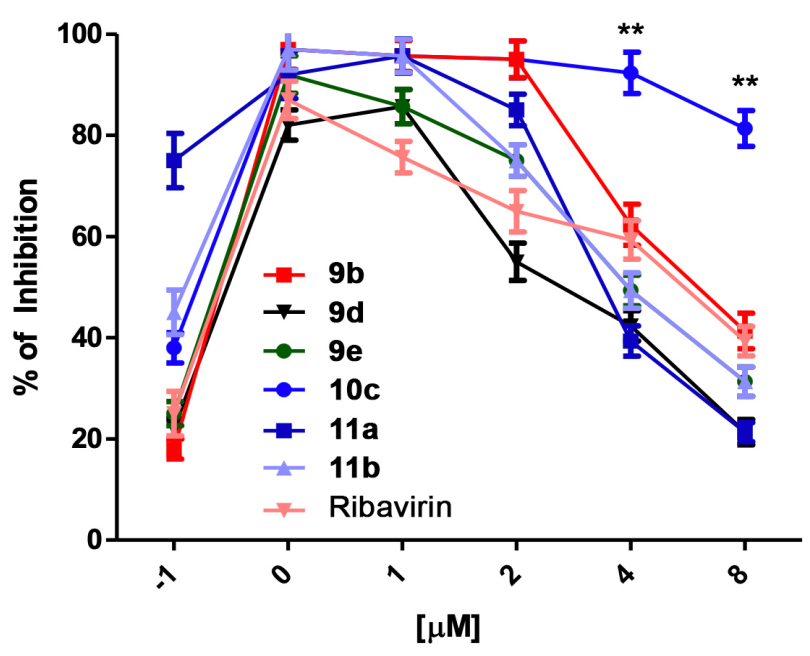

Figure 4. Effect of the addition of the naphthoquinone derivatives on replication over time. Monolayers of Vero cells were infected with CHIKV at an MOI of 0.1 at time -1 , zero, and up to $8 \mathrm{~h}$. At times indicated, compounds or ribavirin was added to a final concentration of $10 \mu \mathrm{gL}^{-1}$. Data are presented as percentage of virus titer, when compared to control cells and are expressed as the mean of three experiments \pm standard error. Statistical analysis was performed using the Tukey's test to compare naphthoquinone derivatives with ribavirin in each time: ${ }^{* *} p<0.01$.

essential in post-entry stages, like capsid protein (protease domain), nsP2 (helicase and protease domains), and nsP3 (macro domain).

Among the proteins evaluated, 10c exhibited the highest theoretical binding affinity with nsP3 $\left(-9.02 \mathrm{kcal} \mathrm{mol}^{-1}\right)$. 10c showed a slightly bent conformation bound to nsP3, which is very similar to the co-crystallized ligand ADP-ribose (Figure 5). The naphthoquinone ring of 10c occupied the same region of the phosphates and distal ribose groups and was hydrogen-bonded to V33, C34, and Y114. Also, we observed that this ring was involved in a T-shaped $\pi-\pi$ stacking interaction with Y114 and van der Waals contacts with $\mathrm{N} 24$ and V113. The sulfonamide and the central phenyl groups of $\mathbf{1 0 c}$ were positioned at the binding region of the co-crystallized ligand adenosine ribose. They established a double hydrogen-bond with L108 and a van der Waals contact with G112. The naphthalene moiety bound in the same region as observed for the adenine group of ADP-ribose and established van der Waals interactions with I11, C143, and R144.

Furthermore, the extended effect observed in the time-of-addition assay suggested that this compound may have a multi-target mechanism of action. 10c showed the second strongest binding affinity with $\mathrm{nsP} 2$ protease $\left(-7.08 \mathrm{kcal} \mathrm{mol}^{-1}\right)$. Also, we docked the known inhibitor D9 18 with this protease for comparison purposes. 10c presented an extended binding mode as observed for the inhibitor (Figure 5). The naphthoquinone ring was positioned in the $\mathrm{S} 2$ subsite. This molecule was anchored by several interactions, such as a hydrogen bond with W1084,
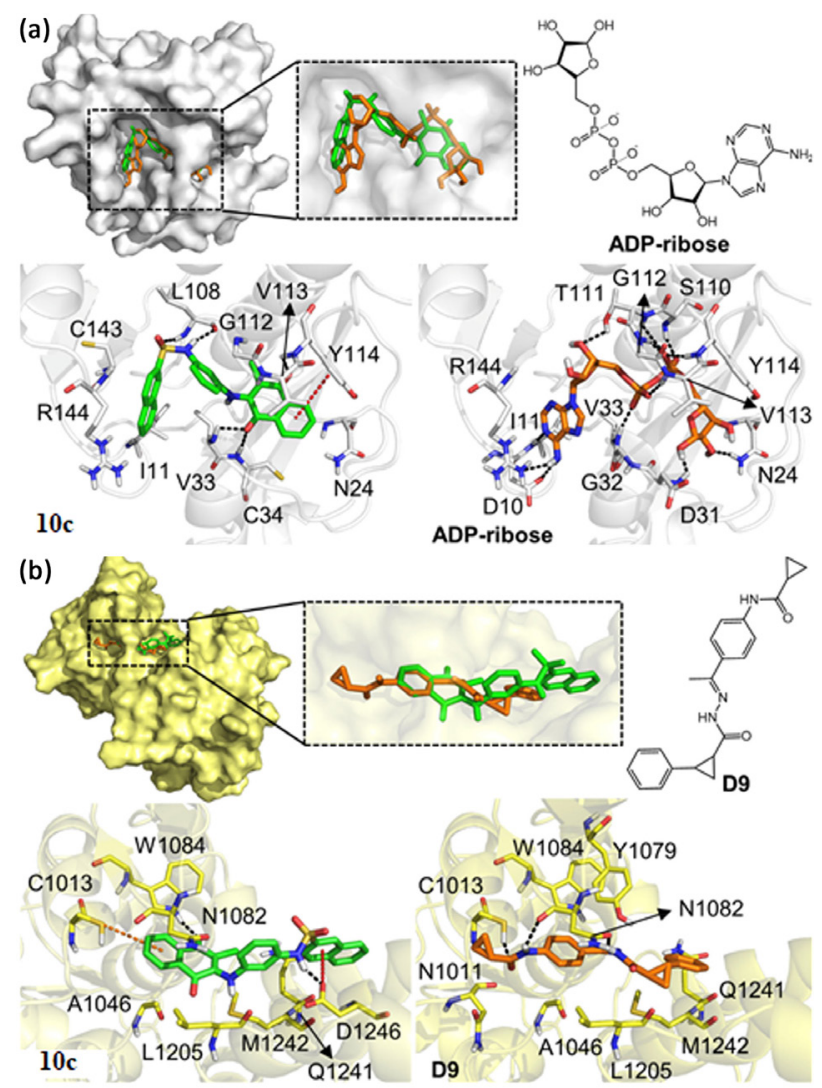

Figure 5. Docking of 10c with its potential anti-CHIKV targets. Binding mode and molecular interactions of (a) 10c (green) and the co-crystallized inhibitor adenosine diphosphate ribose (ADP-ribose, orange) with the macro domain of nsP3, and (b) 10c (green) and the known inhibitor D9 (orange) with the nsP2 protease. Hydrogen bonds are described as black dashed lines, anion- $\pi$ or $\pi-\pi$ stacking interactions are shown as red dashed lines, and $\pi$-sulfur interaction is represented as orange dashed line.

a $\pi$-sulfur interaction with the catalytic $\mathrm{C} 1013$ residue, and van der Waals contacts with A1046, N1082, and L1205. The central phenyl group of 10c bound at the S3 subsite of the protease and interacted with M1242. Like the distal phenyl and cyclopropyl rings of D9, the sulfonamide and naphthalene groups of 10c explored the S4 subsite. The sulfonamide group was hydrogen-bonded with D1246. This residue was also anchoring the naphthalene ring by an anion- $\pi$ interaction in addition to the van der Waals contact with Q1241.

Moreover, 10c was docked to the capsid protein and nsP2 helicase. However, it had the lowest theoretical affinity ( -6.25 and $-5.50 \mathrm{kcal} \mathrm{mol}^{-1}$ for the active and capsid protein hydrophobic sites, respectively, and $-5.06 \mathrm{kcal} \mathrm{mol}^{-1} \mathrm{nsP} 2$ helicase). This prototype did not exhibit a binding manner similar to known ligands of these proteins (data not shown).

\section{In silico target prediction of 11a}

Unlike 10c, 11a showed a direct effect on virus particles and acted in the early stages of the CHIKV lifecycle. So, we investigated in silico whether this compound could bind 
to the envelope proteins and the nsP2 protease and helicase domains and nsP3 macro domain.

11a showed the highest theoretical affinity with the macro domain of nsP3 $\left(-5.10 \mathrm{kcal} \mathrm{mol}^{-1}\right)$. The naphthoquinone moiety was aligned with the adenosine ribose group of ADP-ribose and was involved in a hydrogen bond interaction with L108 and van der Waals contacts with A22, V33, T111, and W148 (Figure 6a). On the other hand, the sulfone and phenyl groups were positioned at the same binding region as observed for the known ligand phosphates and distal ribose. Consequently, 11a was allowed to establish similar interactions with the protein. The sulfone group interacted with V33 and V113 by hydrogen bonding. Besides, the phenyl ring was $\pi$-stacked with Y114 and interacted with V113 via van der Waals contact.

(a)
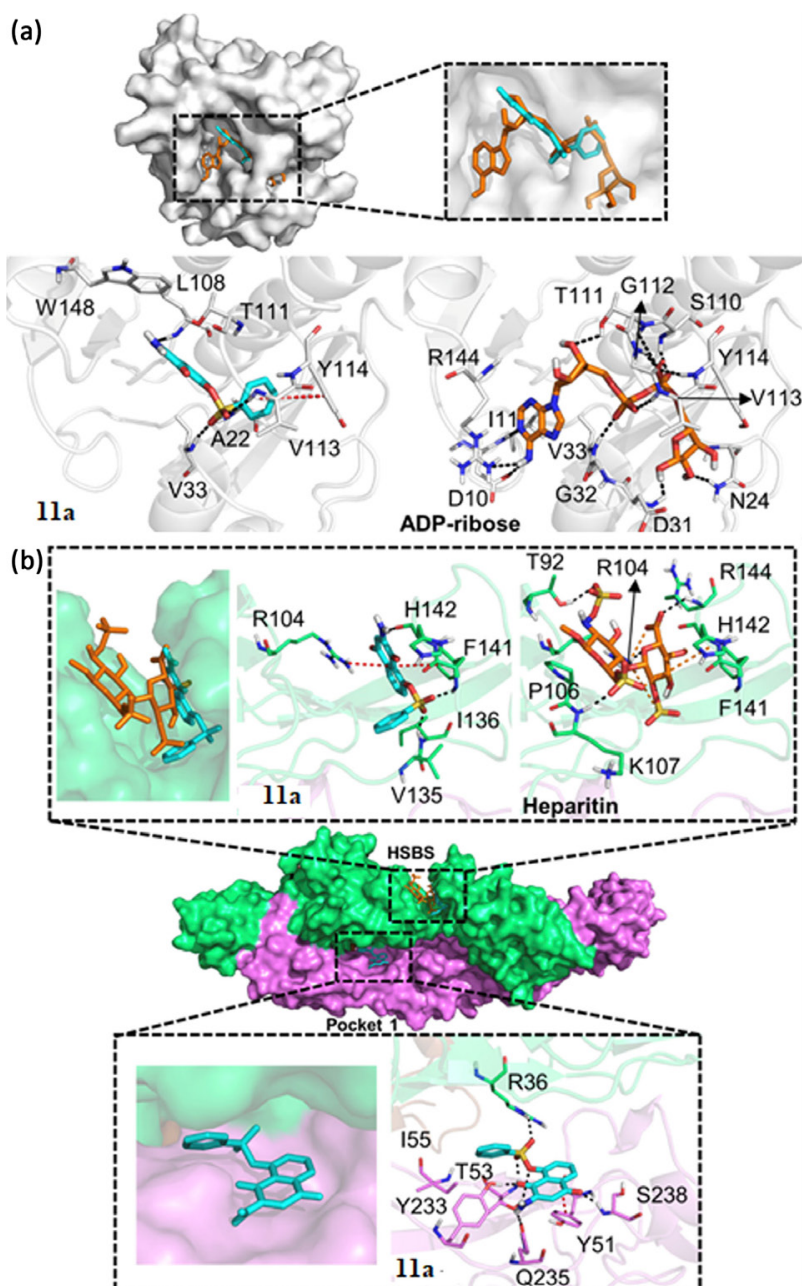

Figure 6. Docking of 11a with its potential anti-CHIKV targets. Binding mode and molecular interactions of (a) 11a (cyan) and the co-crystallized inhibitor ADP-ribose (orange) with the macro domain of nsP3, and (b) 11a (cyan) and the heparan sulfate disaccharide, heparitin (orange), within the heparan-sulfate binding site (HSBS) and pocket 1 of the CHIKV envelope protein complex. E1, E2, and E3 are colored in violet, green and brown, respectively. Hydrogen bonds are exhibited as black dashed lines, cation- $\pi$ or $\pi-\pi$ stacking interactions are shown as red dashed lines, and ionic interactions are represented as orange dashed lines.
Following nsP3, 11a showed the second strongest theoretical affinity with the CHIKV envelope proteins. Two binding sites were explored, and 11a presented a similar affinity towards pocket $1\left(-4.57 \mathrm{kcal} \mathrm{mol}^{-1}\right)$ compared to the heparan-sulfate-binding site $\left(-4.46 \mathrm{kcal} \mathrm{mol}^{-1}\right)$. At pocket 1 , the naphthoquinone nucleus was $\pi$-stacked with Y51 and hydrogen-bonded to Y233 and S238 of E1 (Figure 6b). Also, the sulfone group established hydrogen bond interactions with the side chain of R36 of E2 and with the principal and side chains of T53 of E1, while the phenyl ring was involved in van der Waals contacts with I55 from E1. For the heparan-sulfate binding site, the naphthoquinone ring was sandwiched between R104 and F141 by cation- $\pi$ and $\pi-\pi$ stacking interactions, respectively, while the amino group was hydrogen-bonded to H142 (Figure 6b). The sulfone group established hydrogen bond interactions with V135 and F141, whereas the phenyl ring was involved in a van der Waals interaction with I136. Interestingly, we observed that 11a explored the same binding region as one of the sulfated saccharide nuclei of heparitin (a heparan sulfate disaccharide used as a control herein) and shared interactions R104, F141, and H142. Additionally, 11a showed the lowest theoretical binding affinity with both protease and helicase domains of CHIKV nsP2 (-4.35 and $-3.61 \mathrm{kcal} \mathrm{mol}^{-1}$, respectively) (data not shown).

The cell viability assay revealed a low toxic potential for all compounds. Remarkably, compounds $9 \mathbf{b}, 9 e, 10 c, 11 a$, and 11b exhibited potent inhibitory activity with a highly selective index. We highlight compounds $9 e$ and 10c that presented $\mathrm{EC}_{50}$ equal to 1.18 and $0.77 \mu \mathrm{M}$, generating SI of 457 and 418 , respectively. In contrast, ribavirin, which is an escort drug for clinical use and used as a control, shows a lower inhibitory potential with $2.42 \mu \mathrm{M}$ of $\mathrm{EC}_{50}$ and SI of 122.

Compound 11a showed a virucidal effect above $40 \%$ at $5 \mu \mathrm{M}$, reaching above $70 \%$ at $20 \mu \mathrm{M}$, demonstrating that possibly most of its antiviral effects are at the earliest moments of the viral infection process. These results are in accordance with the time-of-addition assays showed that all compounds already had an antiviral effect at time 0 to infection. The addition time tests showed that although all compounds already had an antiviral effect at time 0 of infection, compound 11a already has an early inhibitory potential $(-1)$ that is, still in pre-treatment, maintaining its inhibitory potential until $2 \mathrm{~h}$ post-infection, with its inhibitory potential declining rapidly, reaching an inhibitory effect of less than $40 \%$ at $4 \mathrm{~h}$ post-infection (Figure 4 ).

We highlight compounds $9 \mathrm{e}\left(\mathrm{CC}_{50}=540\right)$ and 10c $\left(\mathrm{CC}_{50}=322\right)$ and they presented $\mathrm{EC}_{50}$ equal to 1.18 and $0.77 \mu \mathrm{M}$, generating SI of 457 and 418 , respectively. These results prove to be promising, requiring further studies that 
can describe in greater depth the mechanism of action of these compounds. Taking into account that there are no specific medicines for the treatment of infections caused by arboviruses, it is important to search for substances that can be used in the control, treatment and prevention of these infections in order to reduce morbidity and mortality rates caused by CHIKV.

In contrast, compound 11a presented a differentiated profile consistent with action on events before entry. Only the compound 10c showed an inhibitory effect consistent with post-infection effects. In silico studies, some molecular targets may explain these differences in these compound mechanisms of action. Therefore, our results indicate that these compounds can serve as promising scaffolds for developing specific inhibitors for the proliferation of CHIKV.

According to the experimental assay, we conducted computational studies to get more insights into the antiviral targets of the most potent compounds 10c and 11a. Both compounds showed the strongest binding affinity with the macro domain of nsP3. Many contacts observed for both compounds (e.g., V33, T111, V113, and Y114) were proved to be essential for ligand binding into the macro domain of CHIKV nsP3 by structural and computational methods, which reinforces the potential of these naphthoquinone derivatives to inhibit this enzyme. Interestingly, the druggability of CHIKV nsP3 has been recently demonstrated. ${ }^{44,45}$ The precise role of this protein in CHIKV replication remains to be fully understood, but it is essential for several steps in virus replication like genome replication, viral assembly, and host cell shutoff. ${ }^{46,47}$ This protein is also involved in the virulence and pathogenesis of the alphaviruses. ${ }^{48,49}$

Although these derivatives likely share a similar target at early steps of virus replication, the mechanistic studies indicated that these compounds might act at different targets as well. The activity of $\mathbf{1 0 c}$ was prolonged and observed only at post-entry steps. Our in silico strategy also suggested that it could also inhibit the $\mathrm{CHIKV} n \mathrm{nP} 2$ protease. This protein is responsible for the polyprotein processing of CHIKV, which is crucial for virus replication..$^{50,51}$ Despite the lack of experimental data regarding the structural basis for CHIKV nsP2 protease inhibition, mutation and computational studies have provided valuable information to date. For instance, C1013, N1082, H1083, and W1084 are required for the maintenance of the protease activity of alphavirus nsP2..$^{52,53}$ In this context, the hydrogen bond with W1084 seems to be a critical interaction for its inhibition. ${ }^{54,55}$ As well, interactions with residues C1013, A1046, N1082, W1084, and L1205 are commonly observed in the design of novel inhibitors. ${ }^{56}$ It is important to note that $\mathbf{1 0 c}$ interacted with all these residues like the known inhibitor D9.

Additionally, inhibitors of CHIKV nsP2 protease have shown their antiviral activity at the early stages of viral replication, which agrees with the experimental data obtained in this work. ${ }^{57,58}$

On the other hand, 11a was also shown to act directly on virus particles. Interestingly, this compound showed the second-highest theoretical binding affinity with two sites of the CHIKV envelope protein. Pocket 1 was predicted by computational tools and is found between the domain II of E1 and $\beta$-ribbon of E2. Targeting this site could stabilize the envelope complex, prevent E1-E2 dissociation, and, consequently, block fusion process. ${ }^{59}$ Indeed, 11a presented similar interactions as potential ligands of this site. ${ }^{35,54}$ Additionally, 11a bound to the heparan-sulfate binding site with a similar affinity as heparitin. It could establish important interactions like the one with the key residue R104, which, in turn, could impair the virus-cell interaction and inhibit the virus entry. In either case, the binding towards envelope proteins may contribute to inhibition of the viral particle production observed when the compound is added during or a little after virus attachment. ${ }^{34}$ Our results showed the promising potential of $10 \mathbf{c}$ and $11 \mathbf{a}$, and further experimental assays with the putative targets should be performed to confirm our predictions.

\section{Conclusions}

In this work, we report the synthesis of nineteen compounds containing a sulfonamide or sulfonate group attached to a naphthoquinone framework. The compounds were assessed in vitro for their anti-viral activity towards CHIKV. The cell viability assay revealed low toxic potential for all compounds. Remarkably, compounds 9b, 9e, 10c, 11a and 11b exhibited potent inhibitory activity with high selective index. Among them, the compound 11a also showed strong virucide effect. Time-of-addition assays showed that all compounds already had an antiviral effect at time 0 to infection, whereas the compound 11a presented a differentiated profile consistent with post entry inhibitory action with a virucidal effect above $40 \%$ at $5 \mu \mathrm{M}$, reaching above $70 \%$ at $20 \mu \mathrm{M}$, demonstrating that possibly most of its antiviral effects are at the earliest moments of the viral infection process. Collectively, our findings also suggested that 10c and 11a share the macro domain of nsP3 as a common antiviral target. In addition, 10c likely inhibits the nsP2 protease, while 11a seems to bind to the envelope protein to inhibit virus entry and fusion processes as well.

\section{Supplementary Information}

Supplementary data are available free of charge at http://jbcs.sbq.org.br as PDF file. 


\section{Acknowledgments}

This work was partially supported by FAPERJ grant numbers E-26/203.191/2017, E-26/010.101106/2018, E-26/202.800/2017, E-26/010.003002/2014, E-26/203.246/2017, and E-26/202.353/2019; CNPq 301873/2019-4, 306011/2020-4, 308755/2018-9, and CAPES Financial Code 001.

\section{Author Contributions}

Paulo A. F. Pacheco was responsible for organic synthesis work; Daniel T. Gonzaga for organic synthesis work; Cláudio C. CirneSantos for biological assays work; Caroline S. Barros for biological assays work; Max W. L. Gomes for biological assays work; Rafaela S. P. Gomes for biological assays work; Mariana C. Gonçalves for biological assays work; Vitor F. Ferreira for coordination of organic synthesis work, contributions to manuscript writing; Vitor W. Rabelo for biological assays work; Paula A. Abreu for biological assays work; Robson X. Faria for coordination of biological assays, contributions to manuscript writing; Gabriel O. de Resende for coordination of organic synthesis work, contributions to manuscript writing; David R. da Rocha for coordination of organic synthesis work, contributions to manuscript writing; Izabel C. N. de P. Paixão for biological assays work; Fernando C. da Silva for coordination of organic synthesis work, contributions to manuscript writing.

\section{References}

1. Thomson, R. H.; Naturally Occurring Quinones IV; Springer: Netherlands, 1996.

2. Monks, T.; Jones, D.; Curr. Drug Metab. 2005, 3, 425.

3. Dias, F. R. F.; Guerra, F. S.; Lima, F. A.; de Castro, Y. K. C.; Ferreira, V. F.; Campos, V. R.; Fernandes, P. D.; Cunha, A. C.; J. Braz. Chem. Soc. 2021, 32, 476.

4. Novais, J. S.; Rosandiski, A. C.; de Carvalho, C. M.; Silva, L. S. S.; de Souza, L. C. S. V.; Santana, M. V.; Martins, N. R. C.; Castro, H. C.; Ferreira, V. F.; Gonzaga, D. T. G.; de Resende, G. O.; da Silva, F. C.; Curr. Top. Med. Chem. 2019, 20, 121 .

5. Luo, P.; Wong, Y. F.; Ge, L.; Zhang, Z. F.; Liu, Y.; Liu, L.; Zhou, H.; J. Pharmacol. Exp. Ther. 2010, 335, 735.

6. Wang, R.; Hu, Q.; Wang, H.; Zhu, G.; Wang, M.; Zhang, Q.; Zhao, Y.; Li, C.; Zhang, Y.; Ge, G.; Chen, H.; Chen, L.; Int. J. Biol. Macromol. 2021, 183, 182.

7. BACTRIM ${ }^{\mathrm{TM}}$; https://www.accessdata.fda.gov/drugsatfda_docs/ label/2003/17377slr057_Bactrim_lbl.pdf, accessed in January 2022.

8. Qiu, H. Y.; Wang, P. F.; Lin, H. Y.; Tang, C. Y.; Zhu, H. L.; Yang, Y. H.; Chem. Biol. Drug Des. 2018, 91, 681.

9. Hook, I.; Mills, C.; Sheridan, H. In Studies in Natural Products
Chemistry; Atta-ur-Rahman, ed.; Elsevier: Oxford, 2014, ch. 5.

10. Rougeron, V.; Sam, I. C.; Caron, M.; Nkoghe, D.; Leroy, E.; Roques, P.; J. Clin. Virol. 2015, 64, 144.

11. Plotkin, S. A.; J. Pediatr. Infect. Dis. Soc. 2019, 8, 95.

12. Kucharz, E. J.; Cebula-Byrska, I.; Eur. J. Intern. Med. 2012, 23,325 .

13. Weaver, S. C.; Lecuit, M.; N. Engl. J. Med. 2015, 372, 1231.

14. Sharif, N.; Sarkar, M. K.; Ferdous, R. N.; Ahmed, S. N.; Billah, M. B.; Talukder, A. A.; Zhang, M.; Dey, S. K.; Front. Microbiol. 2021, 12, 689979.

15. Silva, J. V. J.; Ludwig-Begall, L. F.; de Oliveira-Filho, E. F.; Oliveira, R. A. S.; Durães-Carvalho, R.; Lopes, T. R. R.; Silva, D. E. A.; Gil, L. H. V. G.; Acta Trop. 2018, 188, 213.

16. McArthur, D. B.; Nurs. Clin. North Am. 2019, 54, 297.

17. Hucke, F. I. L.; Bugert, J. J.; Front. Public Health 2020, 8, 618624.

18. Acetazolamide; https://www.drugs.com/monograph/ acetazolamide.html, accessed in January 2022.

19. CDER Statement: FDA Approves Labeling Supplement for Celebrex (celecoxib); https://www.fda.gov/drugs/drugsafety-and-availability/cder-statement-fda-approves-labelingsupplement-celebrex-celecoxib, accessed in January 2022.

20. Diaßeta ${ }^{\circledR}$ (glyburide) Tablets USP; https://www.accessdata.fda. gov/drugsatfda_docs/label/2009/017532s030lbl.pdf, accessed in January 2022.

21. Murthy, I. S.; Sireesha, R.; Deepti, K.; Srinivasa Rao, P.; Ramesh Raju, R.; Chem. Data Collect. 2021, 31, 100608.

22. Uma Priya, K.; Venkataramaiah, C.; Sreedhar, N. Y.; Raju, C. N.; RSC Adv. 2021, 11, 3897.

23. Manolov, S. P.; Ivanov, I. I.; Bojilov, D. G.; J. Serb. Chem. Soc. 2021, 86, 139.

24. Gulçin, İ.; Taslimi, P.; Expert Opin. Ther. Pat. 2018, 28, 541.

25. AGENERASE ${ }^{T \mathrm{M}} ;$ https://www.accessdata.fda.gov/drugsatfda docs/label/1999/21007lbl.pdf, accessed in January 2022.

26. PREZISTA (darunavir); https://www.accessdata.fda.gov/ drugsatfda_docs/label/2012/021976s021lbl.pdf, accessed in January 2022.

27. Cirne-Santos, C. C.; Barros, C. S.; Nogueira, C. C. R.; Azevedo, R. C.; Yamamoto, K. A.; Meira, G. L. S.; de Vasconcelos, Z. F. M.; Ratcliffe, N. A.; Teixeira, V. L.; Schmidt-Chanasit, J.; Ferreira, D. F.; Paixão, I. C. N. P.; Front. Microbiol. 2019, 10, 2426.

28. Mosmann, T.; J. Immunol. Methods 1983, 65, 55.

29. 3N42. Crystal Structures of the Mature Envelope Glycoprotein Complex (furin cleavage) of Chikungunya virus; https://www. rcsb.org/structure/3N42, accessed in January 2022.

30. 5H23. Crystal Structure of Chikungunya Virus Capsid Protein; https://www.rcsb.org/structure/5H23, accessed in January 2022.

31. 3TRK. Structure of the Chikungunya Virus nsP2 Protease; https://www.rcsb.org/structure/3TRK, accessed in January 2022. 
32. 6JIM. Viral Helicase Protein; https://www.resb.org/ structure/6JIM, accessed in January 2022.

33. 3GPO. Crystal Structure of Macro Domain of Chikungunya Virus in Complex with ADP-ribose; https://www.rcsb.org/ structure/3GPO, accessed in January 2022.

34. Spartan, version 10; Wavefunction, Inc., Japan Branch Office, Japan, 2011.

35. Molecular Graphics Laboratory; Autodock Tools, version 1.5.7; The Scripps Research Institute, USA, 2010.

36. Sahoo, B.; Chowdary, T. K.; Biosci. Rep. 2019, 39, BSR20191077.

37. Nguyen, P. T. V.; Yu, H.; Keller, P. A.; Interdiscip. Sci.: Comput. Life Sci. 2018, 10, 515.

38. Sharma, R.; Kesari, P.; Kumar, P.; Tomar, S.; Virology 2018, 515,223

39. Discovery Studio Visualizer 2019, Dassault Systèmes BIOVIA, San Diego, 2019.

40. The PyMOL Molecular Graphics System, Pymol, version 2.5; Schrödinger, LLC, 2018.

41. GraphPad InStat, version 3; GraphPad Software, Inc.; USA, 2001.

42. Couladouros, E. A.; Plyta, Z. F.; Haroutounian, S. A.; Papageorgiou, V. P.; J. Org. Chem. 1997, 62, 6.

43. Giordano, A.; Powers, G. D.; Sturgess, M. A.; Yang, K.; US6630589-B1, 2007.

44. Malet, H.; Coutard, B.; Jamal, S.; Dutartre, H.; Papageorgiou, N.; Neuvonen, M.; Ahola, T.; Forrester, N.; Gould, E. A.; Lafitte, D.; Ferron, F.; Lescar, J.; Gorbalenya, A. E.; de Lamballerie, X.; Canard, B.; J. Virol. 2009, 83, 6534.

45. Puranik, N. V.; Rani, R.; Singh, V. A.; Tomar, S.; Puntambekar, H. M.; Srivastava, P.; ACS Omega 2019, 4, 20335.

46. Abraham, R.; Hauer, D.; McPherson, R. L.; Utt, A.; Kirby, I. T.; Cohen, M. S.; Merits, A.; Leung, A. K. L.; Griffin, D. E.; Proc. Natl. Acad. Sci. U. S. A. 2018, 115, E10457.

47. Gao, Y.; Goonawardane, N.; Ward, J.; Tuplin, A.; Harris, M.; PLoS Pathog. 2019, 15, e1007239.

48. Abraham, R.; McPherson, R. L.; Dasovich, M.; Badiee, M.; Leung, A. K. L.; Griffin, D. E.; mBio 2020, 11, e03253.

49. Meertens, L.; Hafirassou, M. L.; Couderc, T.; Bonnet-Madin,
L.; Kril, V.; Kümmerer, B. M.; Labeau, A.; Brugier, A.; Simon-Loriere, E.; Burlaud-Gaillard, J.; Doyen, C.; Pezzi, L.; Goupil, T.; Rafasse, S.; Vidalain, P. O.; Bertrand-Legout, A.; Gueneau, L.; Juntas-Morales, R.; Ben Yaou, R.; Bonne, G.; de Lamballerie, X.; Benkirane, M.; Roingeard, P.; Delaugerre, C.; Lecuit, M.; Amara, A.; Nature 2019, 574, 259.

50. Rupp, J. C.; Sokoloski, K. J.; Gebhart, N. N.; Hardy, R. W.; J. Gen. Virol. 2015, 96, 2483.

51. Shin, G.; Yost, S. A.; Miller, M. T.; Elrod, E. J.; Grakoui, A.; Marcotrigiano, J.; Proc. Natl. Acad. Sci. U. S. A. 2012, 109, 16534.

52. Narwal, M.; Singh, H.; Pratap, S.; Malik, A.; Kuhn, R. J.; Kumar, P.; Tomar, S.; Int. J. Biol. Macromol. 2018, 116, 451.

53. Strauss, E. G.; de Groot, R. J.; Levinson, R.; Strauss, J. H.; Virology 1992, 191, 932.

54. Giancotti, G.; Cancellieri, M.; Balboni, A.; Giustiniano, M.; Novellino, E.; Delang, L.; Neyts, J.; Leyssen, P.; Brancale, A.; Bassetto, M.; Eur. J. Med. Chem. 2018, 149, 56.

55. Tardugno, R.; Giancotti, G.; de Burghgraeve, T.; Delang, L.; Neyts, J.; Leyssen, P.; Brancale, A.; Bassetto, M.; Bioorg. Med. Chem. 2018, 26, 869.

56. Rabelo, V. W. H.; Paixão, I. C. N. P.; Abreu, P. A.; Expert Opin. Ther. Targets 2020, 24, 63.

57. Das, P. K.; Puusepp, L.; Varghese, F. S.; Utt, A.; Ahola, T.; Kananovich, D. G.; Lopp, M.; Merits, A.; Karelson, M.; Antimicrob. Agents Chemother. 2016, 60, 7382.

58. Singh, H.; Mudgal, R.; Narwal, M.; Kaur, R.; Singh, V. A.; Malik, A.; Chaudhary, M.; Tomar, S.; Biochimie 2018, 149, 51.

59. Rashad, A. A.; Keller, P. A.; J. Mol. Graphics Modell. 2013, 44, 241.

Submitted: October 29, 2021

Published online: January 12, 2022 